NBER WORKING PAPER SERIES

\title{
CEO PREFERENCES AND ACQUISITIONS
}

\author{
Dirk Jenter \\ Katharina Lewellen \\ Working Paper 17663 \\ http://www.nber.org/papers/w17663
NATIONAL BUREAU OF ECONOMIC RESEARCH
1050 Massachusetts Avenue
Cambridge, MA 02138
December 2011

We are grateful for comments and suggestions from Kenneth Ahern, John Graham, Simi Kedia, Kevin J. Murphy, Francisco Perez-Gonzalez, Adriano Rampini, Myron Scholes, Geoffrey Tate, Ivo Welch, Rebecca Zarutskie, Jeffrey Zwiebel, seminar participants at the University of Michigan, Nanyang Technological University, National University of Singapore, Singapore Management University, Stanford University, Hong Kong University of Science and Technology, and conference participants at the 2011 Econometric Society Meeting, the 2011 Western Finance Association Meeting, the 2011 Duke-UNC Corporate Finance Conference, and the 2011 SFS Cavalcade. The views expressed herein are those of the authors and do not necessarily reflect the views of the National Bureau of Economic Research.

NBER working papers are circulated for discussion and comment purposes. They have not been peerreviewed or been subject to the review by the NBER Board of Directors that accompanies official NBER publications.

(C) 2011 by Dirk Jenter and Katharina Lewellen. All rights reserved. Short sections of text, not to exceed two paragraphs, may be quoted without explicit permission provided that full credit, including (C notice, is given to the source. 
CEO Preferences and Acquisitions

Dirk Jenter and Katharina Lewellen

NBER Working Paper No. 17663

December 2011

JEL No. D22,D23,G3,G30,G34

\begin{abstract}
This paper explores the impact of target CEOs' retirement preferences on the incidence, the pricing, and the outcomes of takeover bids. Mergers frequently force target CEOs to retire early, and CEOs' private merger costs are the forgone benefits of staying employed until the planned retirement date. Using retirement age as an instrument for CEOs' private merger costs, we find strong evidence that target CEO preferences affect merger patterns. The likelihood of receiving a takeover bid increases sharply when target CEOs reach age 65 . The probability of a bid is close to $4 \%$ per year for target CEOs below age 65 but increases to $6 \%$ for the retirement-age group, a $50 \%$ increase in the odds of receiving a bid. This increase in takeover activity appears discretely at the age-65 threshold, with no gradual increase as CEOs approach retirement age. Moreover, observed takeover premiums and target announcement returns are significantly lower when target CEOs are older than 65, reinforcing the conclusion that retirement-age CEOs are more willing to accept takeover offers. These results suggest that the preferences of target CEOs have first-order effects on both bidder and target behavior.
\end{abstract}

Dirk Jenter

Stanford University

Graduate School of Business

655 Knight Way

Stanford, CA 94305-5015

and NBER

djenter@stanford.edu

Katharina Lewellen

Tuck School at Dartmouth

100 Tuck Hall

Hanover, NH 03755

katharina.lewellen@tuck.dartmouth.edu 


\section{Introduction}

From 1990 to 2008, close to 7,800 public U.S. firms were acquired. For the 5,537 target firms for which we have data, the total market capitalization exceeded \$5.0 trillion. In the median transaction, target shareholders received a premium of $35 \%$ over the preannouncement share price, and the total value increase from all deals combined was about $\$ 1.4$ trillion. These magnitudes suggest that the takeover market has great potential to create or destroy shareholder value. This paper provides evidence that the career concerns and retirement preferences of target firms' CEOs have first-order effects on takeover decisions, leading to outcomes that are unlikely to be in the target shareholders' best interest.

The target firm's CEO is, arguably, one of the most important actors in the takeover market. As the top executive of the target, the CEO plays a key role in her firm's decisions leading up to a bid (e.g., the decision to seek out a buyer, or to initiate merger talks), and once a bid is made, the CEO leads her firm's response and its negotiations with buyers. Given this unique role, it is interesting to note that target CEOs' career concerns and retirement preferences are likely to be at odds with target shareholders' objectives: target CEOs typically lose their jobs during or shortly after a takeover, and in only a handful of cases does the departing CEO find a new position in a public firm (see for example, Martin and McConnell (1991) and Agrawal and Walkling (1994)). In many cases, mergers force target CEOs into early retirement, ending their CEO careers entirely. This suggests that mergers can represent serious setbacks to target CEOs' careers. Though most CEO compensation contracts recognize these costs - they include golden parachutes or special bonuses conditional on mergers - it is unclear to what extent they succeed at eliminating the inherent incentive problem.

In this paper, we test whether target CEOs’ retirement preferences affect the incidence, the pricing, and the outcomes of takeover bids. If mergers force target CEOs to retire early, then the CEOs' private merger costs are the forgone benefits of staying employed until the planned retirement date. Though retirement plans differ across individuals, research in labor economics shows that a disproportional fraction of workers retires at the age of 65 (we observe the same phenomenon for CEOs). This age-65 effect cannot be fully explained by monetary incentives, including social security benefits or Medicare, which suggests behavioral explanations related to customs or social norms. If CEOs similarly favor 65 as 
retirement age, this preference should be reflected in their private merger costs, and provided that these costs affect merger decisions - in the observed merger patterns. Specifically, one should observe an increase in merger activity as CEOs approach 65, or a discrete jump in this activity at the age-65 threshold (we derive these predictions in Section 2).

We find strong evidence that target CEOs' retirement preferences affect merger patterns. In data on U.S. public firms from 1992 to 2008, the likelihood of a takeover bid increases sharply when the target CEO reaches age 65. Controlling for CEO and firm characteristics, the implied probability that a firm receives a takeover bid is close to $4 \%$ per year for CEOs below the retirement age (e.g., in age groups 56-60 and 61-65), but it increases to $6 \%$ for the retirement-age group (above age 65). This corresponds to a 50\% increase in the odds of receiving a bid, and the effect is statistically significant at the $1 \%$ level. The increase in takeover activity appears abruptly at the age-65 threshold, with no gradual increase as CEOs approach retirement age. The effect is similar whether all bids or only successful bids are included, and it remains economically large and significant even when CEO age and age squared are included separately as controls. These results show that bidders are more likely to target firms with retirement-age CEOs, possibly due to these CEOs' weaker expected resistance against takeover bids.

We next examine the effect of CEOs' retirement preferences on target shareholders' gains from acquisitions. A target CEO's attitude towards a merger bid is likely to be influenced by both the CEO's private costs and by the expected impact of the merger on target shareholder value. CEOs pay attention to shareholder value because they themselves hold equity in their firms, and because of pressure from boards to maximize shareholder wealth. This implies that a CEO with lower private costs will require a smaller gain for shareholders to approve a merger deal. Thus, if retirement-age CEOs face lower private costs, then they should allow more mergers to go through (as we document), and the incremental deals should generate lower shareholder gains on average.

Consistent with this prediction, observed takeover premiums and target announcement returns are significantly lower when target CEOs are above 65. Controlling for firm, CEO, and deal characteristics, the takeover premium measured from one month before the first bid announcement to the final offer price is eight to ten percentage points lower when the target has a retirement-age CEO. This effect is both statistically significant and economically large. 
There is no difference in the pre-announcement stock price run-ups between targets with above- and below-65 CEOs, though we cannot rule out that some of the difference in takeover premiums is caused by differences in investors' expectations about the likelihood of a bid. Interestingly, acquirer announcement returns are on average zero in both the retirement-age and the below-65 samples, suggesting that the bargaining power in merger negotiations remains with the target firm regardless of the age of its CEO.

Finally, the discrete increase in the likelihood of receiving a bid at age 65 is not limited to full takeover bids. We discover a similar pattern in a sample of bids for partial stakes, which are bids for less than $50 \%$ of the target's equity. Some of these transactions are likely to be a direct consequence of the more active takeover market in the retirement-age sample. For example, investors may purchase target shares in anticipation of a takeover bid, or potential acquirers may accumulate toeholds to reduce future acquisition costs. Consistent with the first motive, we find that most partial acquisitions in the retirement-age sample are openmarket purchases by passive investors, probably betting that the target share price will rise due to a takeover bid. We discuss additional motives for partial acquisitions in Section 5.

Section 4 of this paper evaluates several alternative explanations for the change in merger patterns as target CEOs reach retirement age. We find little support for the alternative hypotheses in the data. For example, retirement-age CEOs appear to be no more frequent targets of disciplinary takeovers than younger CEOs. There is also no evidence that the more frequent takeovers of firms with above-65 CEOs are due to CEOs' desire to cash out their stock and option holdings, or that they are caused by old interim CEOs who were hired to sell their firms. We also examine the possibility that retirement-age CEOs sell their firms more frequently in order to solve succession problems. While it is difficult to rule out this explanation, there is no evidence that the retirement-age effect on takeover frequencies is larger in firms or industries in which we expect succession problems to be more severe.

This paper merges two strands of literature: the literature on managerial career concerns and horizon problems, and the literature on agency conflicts in mergers and acquisitions. With regard to managers' career concerns, Holmström (1982) and Gibbons and Murphy (1992) argue that agency problems worsen as managers approach retirement and care less about their long-term career prospects. In the same vein, Dechow and Sloan (1991) provide evidence that older managers focus excessively on actions with short-term gains. Our results offer a different perspective: they suggest that a shorter horizon can improve corporate 
decisions. Assuming that CEOs are generally too reluctant to sell their firms because of an associated loss of private rents, an approaching retirement mitigates this loss and reduces resistance to takeover bids. More generally, many firm-value maximizing decisions are associated with future costs to CEOs. Such costs should become less important to CEOs as they approach the end of their careers. For example, Jensen $(1986,1993)$ describes managers' reluctance to divest unprofitable operations and shrink their firms, arguably at least in part because running a smaller firm is less enjoyable. Our results suggest that a distortion of this type will be less severe for CEOs close to retirement.

Turning to the M\&A literature, theoretical models of mergers frequently start with the assumption that target CEOs’ preferences affect M\&A decisions (e.g., because of private benefits of control). However, because preferences are unobservable, direct empirical evidence on the role of managers' preferences in mergers is almost non-existent. ${ }^{1}$ Instead, the literature has focused on the effects of target CEOs' explicit incentives, such as equity stakes, on mergers. ${ }^{2}$ For example, Mikkelson and Partch (1989) and Song and Walkling (1993) show that target managers' equity holdings are negatively related to the probability of a takeover bid, while Ambrose and Megginson (1992) find no relation, and Morck, Shleifer, and Vishny (1988) a positive one. Similarly, Stulz, Walkling, and Song (1990) and Song and Walkling (1993) document a positive correlation between target managers' equity stakes and takeover premiums, while Moeller (2005) finds a negative relation. Walkling and Long (1984), Morck et al. (1988), and Cotter and Zenner (1994) find that managers with smaller equity stakes put up more resistance to takeover bids. Finally, both Wulf (2004) and Bargeron, Schlingemann, Stulz, and Zutter (2010) examine the retention of target CEOs by the merged firm and its relation to takeover premiums. Wulf, in a small sample of mergers of equals, finds a negative relation between target CEO retention and premiums, while Bargeron et al., in a broader sample, find no evidence that target CEOs trade lower premiums for continued employment. ${ }^{3}$

While the associations between target CEO incentives and mergers documented in prior studies are interesting, they are difficult to interpret. Both equity holdings and offers of post-

\footnotetext{
${ }^{1}$ An important exception is Bertrand and Schoar (2003) who show that a given CEO's propensity to engage in acquisitions persists across different firms.

${ }^{2}$ An even larger literature examines the effects of bidder CEO incentives and preferences on mergers. See, for example, Lewellen, Loderer, and Rosenfeld (1985), Morck, Shleifer, and Vishny (1990), Denis, Denis, and Sarin (1997), Datta, Iskandar-Datta, and Raman (2001), Grinstein and Hribar (2004), Harford and Li (2007), and Yim (2010).

${ }^{3}$ Bargeron et al. note that CEOs close to retirement negotiate lower takeover premiums, though this result is not the focus of their study.
} 
merger employment are choice variables, are determined jointly with other merger decisions, and can be adjusted quickly by boards. As a result, both variables are likely to be correlated with prior performance, CEO quality, CEO power, and many other unobservable factors that are themselves likely to affect merger patterns.

In comparison, using the presence of a retirement-age CEO as an instrument for low career costs is attractive. The age of the target CEO is not the result of immediate choices by the parties negotiating the merger deal, and changing CEO age requires replacing the CEO. Moreover, as we argue in more detail in the next section, preferences are likely to change for at least some CEOs around age 65, making CEO age a useful proxy for otherwise unobservable preferences. Finally, the fact that merger patterns change abruptly at age 65 suggests that we are in fact capturing an effect of CEO preferences: any other determinants of mergers that are correlated with CEO age are unlikely to change discretely just because a CEO reaches retirement age.

The effects of retirement-age CEOs on mergers documented in this paper should nevertheless not be interpreted as the true causal effects. Instead, what we observe is the combined effect of changing CEO preferences and of boards' reactions to them. There are at least two mechanisms likely to be at work that render retirement-age CEOs endogenous: First, boards make the decision to have a retirement-age CEO. CEOs are bundles of many attributes, making it impossible to have CEOs who are optimal on all dimensions at all times, but CEO age is one of the attributes boards are likely to consider. Second, boards can adjust the terms of CEO compensation contracts, and especially of golden parachutes, to offset CEO preferences that change with CEO age. If career concerns cause younger CEOs to be too reluctant to sell their firms, then boards can mitigate this problem through explicit monetary incentives. ${ }^{4}$ If golden parachutes tied to a successful sale of the firm perfectly compensated CEOs for the loss of future income (and loss of other benefits) associated with being acquired, then one should see no effect of CEO age on mergers. Our empirical evidence shows that golden parachutes, despite being a standard element of CEO compensation contracts, do not eliminate the effect of CEOs' retirement preferences on merger outcomes. However, the observed effects of CEO age on mergers would arguably be even larger without the countervailing effects of golden parachutes.

\footnotetext{
${ }^{4}$ See Knoeber (1986), Harris (1990), and Eisfeldt and Rampini (2008) for models of optimal golden parachutes.
} 
The remainder of the paper is organized as follows. Section 2 discusses motivating evidence and develops the hypotheses. Section 3 describes the data and sample construction, while Section 4 presents the main empirical results. Section 5 shows additional evidence using data on partial acquisitions, and Section 6 concludes.

\section{CEOs' private merger costs and the age-65 effect}

\subsection{CEO's private merger costs}

The prior literature shows that target CEOs typically lose their jobs during or shortly after a takeover, and that the departing CEO only rarely finds a comparable position in a public firm. Walkling and Long (1984), Martin and McConnell (1991), Agrawal and Walkling (1994), Hartzel, Ofek, and Yermack (2004), and Wulf and Singh (2010) all document that target CEOs suffer high turnover rates and poor career prospects following mergers. This suggests that being the target of a takeover bid can impose large career costs on the target CEO. ${ }^{5}$

In addition, standard CEO compensation practices strongly suggest that acquisitions entail direct costs for target CEOs. Most CEO compensation contracts contain golden parachutes and special bonuses that generate often large amounts of additional income for CEOs in case a firm is sold. These widespread arrangements, documented in detail by Hartzel et al. (2004), Bebchuk, Cohen, and Wang (2010) and Fich, Tran, and Walkling (2010), make little sense unless being acquired is costly for target CEOs. ${ }^{6}$

\subsection{The age-65 effect}

Labor economists have studied retirement decisions for decades and have developed models that predict the retirement patterns of U.S. employees. ${ }^{7}$ One puzzling phenomenon is that these models underpredict the frequency of retirements at age 65. For example, in one of

\footnotetext{
${ }^{5}$ Harford (2003) documents similar costs for the target's outside directors. It is worth noting, however, that the observed relationship between acquisitions and career outcomes is not necessarily a causal one. The careers of target CEOs might suffer not because of the acquisitions, but because of, for example, bad performance that causes the acquisition (as well as the decline in the CEO's career).

${ }^{6}$ In the same vein, Fich, Cai, and Tran (2011) and Heitzman (2011) show that target CEOs often receive unscheduled equity grants during merger negotiations. Their evidence suggests that such grants provide bargaining incentives to CEOs and compensate them for future benefits forfeited because of the merger.

${ }^{7}$ See, for example, Hurd and Boskin (1981), Burtless (1986), Hausman and Wise (1985), Stock and Wise (1990a, 1990b), and the overview in Lumsdaine, Wise, and Stock (1990).
} 
the firms studied by Lumsdaine, Stock, and Wise (1996), 48\% of men working at 64 retire at 65. This compares to $21 \%$ of men working at 63 who retire at $64 .{ }^{8}$ Lumsdaine et al. test a number of potential explanations for this age-65 effect. They conclude that the magnitude of the spike cannot be explained by the provisions of Social Security, Medicare, or pension plans. They also argue that for a typical worker aged 64 the cost of retiring at 65 vs. the optimal age is quite high, so that "rule-of-thumb" behavior is unlikely to explain the data. They conclude: "We are inclined to attribute the unexplained high age 65 departure rates to an 'age-65 retirement effect,' that is, to the influence of custom or accepted practice.” Put differently, employees' preferences for work vs. retirement seem to change discretely (or at least rapidly) at age 65.

In this paper, we exploit the age-65 effect to test whether CEOs’ personal preferences affect the likelihood and the outcomes of merger bids. Figure 1 shows that CEO turnovers spike at age 65, very similar to the pattern for rank-and-file employees. Moreover, departure rates are consistently higher after age 65 than before. ${ }^{9}$ There are a number of possible reasons for why more CEOs retire at age 65. First, CEO preferences for work vs. leisure may change around age 65, similar to what the literature suggests for other employees. This may be because CEOs have internalized customary retirement practices into their preferences. Alternatively, it may be because boards put pressure on CEOs to retire, perhaps because they believe that CEO skills deteriorate with age, or because they try to improve the incentives of potential internal successors. If boards' pressure increases sharply at 65, then CEOs may experience a corresponding decline in their utility from employment at that threshold. ${ }^{10}$

What are the implications of the many CEO retirements at age 65 for acquisitions? A straightforward implication is that many 65-year old (or older) CEOs do not lose much by accepting a takeover bid. For younger CEOs, becoming the target of an acquisition usually implies an (involuntary) early retirement, as discussed in the previous section. For a CEO at or close to her expected retirement age, however, the cost of her firm being acquired should be small.

\footnotetext{
${ }^{8}$ See also Phelan and Rust (1997) and Blau (1994).

${ }^{9}$ Similar spikes in CEO turnover at age 65 have been observed by, among others, Gibbons and Murphy (1992), Murphy and Zimmerman (1993), and Weisbach (1995).

${ }^{10}$ Mandatory retirement ages, which most commonly use 65 as the threshold for CEOs, would similarly limit CEOs' horizons at this age. Vancil (1987) reports that $47 \%$ of the 421 firms in his sample have mandatory retirement for CEOs at age 65. Since 1978, the U.S. Age Discrimination in Employment Act prohibits mandatory retirement of "executives and high policy makers" at ages below 65, which implies that any mandatory retirements for CEOs must be at or above 65 .
} 
If CEOs are powerful enough to impose their personal preferences onto their firms' policies, then acquirers should prefer target CEOs who are ready to retire. The exact effect of target CEO age on acquisition patterns around age 65 depends on why exactly CEOs retire at this age. If CEOs' preference for work over leisure gradually declines as they approach 65, then their willingness to sell their firm should gradually increase, and so should the frequency of acquisition bids. Similarly, if CEOs' are concerned about the loss of future income due to an involuntary early retirement, then this concern should gradually diminish as they approach their retirement, again causing a gradual increase in acquisitions. However, if CEOs have a strong preference to stay in office until age 65, or if CEOs' are pressured to retire at age 65 even though they still prefer to work, then we may observe an abrupt increase in takeover activity as CEOs reach retirement age.

\section{Data and descriptive statistics}

\subsection{Data sources}

The acquisition data are from the Securities Data Corporation's (SDC) U.S. Merger and Acquisition Database. To obtain information on target CEOs, we start with the Standard \& Poor's ExecuComp database, which lists top executives in all S\&P 500, S\&P MidCap, and S\&P SmallCap firms starting in 1992. We cross-check this information and collect data on CEO age and on whether a CEO is "interim" by searching news articles in the Factiva database and the firms' proxy statements. For a subset of CEOs, the age data comes from Peters and Wagner (2009). After excluding interim CEOs, the resulting panel data set contains 5,841 CEOs and 32,026 CEO-years from 1992 through 2008. We use financial statement information from Compustat and stock return data from the Center for Research in Security Prices (CRSP).

\subsection{Sample for the bid frequency analysis}

The bid frequency regressions estimate the likelihood that a firm becomes an acquisition target (or is acquired) in a given fiscal year. To identify the acquisition years, we obtain a list of all bids for ExecuComp firms that have announcement dates during our sample period. We exclude share repurchases, privatizations, exchange offers, recapitalizations, cases in which the bidder already owns 50\% or more of the target's equity, and bids with missing data on the amount of target equity sought. Based on this list, we identify the firm-years in the CEO 
panel in which the firm becomes the target of an acquisition bid. ${ }^{11}$ The final data set for the bid frequency regressions has 23,499 CEO-years with complete data, 1,692 of which are classified as years in which the firm is a target. In 1,083 CEO-years, the firm is the target of a control bid, which we define as a bid for at least $50 \%$ of equity.

\subsection{Sample for the takeover premium analysis}

The takeover premium analysis uses a sample of control bids (i.e., bids for at least $50 \%$ of the target's equity) for which SDC indicates that the transaction has been completed. This sample consists of 928 bids and is described in Table 1. After merging with CRSP, Compustat, and CEO characteristics, there are 724 bids with complete data, which is the sample used in the regressions. ${ }^{12}$

To construct the bid announcement returns and takeover premiums, we identify announcement dates using a procedure similar to Betton, Eckbo, and Thorburn (2008). First, we identify bids occurring within six months prior to the completed control bid for a given target. Any control bids that occur within that time period are classified as belonging to the same takeover contest as the final bid. The announcement date used in the analysis is then the announcement date of the first control bid in each contest. In $90 \%$ of cases, there are no control bids preceding the final bid.

\subsection{Descriptive statistics}

Descriptive statistics for the 928 completed control bids are in Table 1. The table distinguishes between bids received by CEOs above and below the age-65 retirement threshold. Target firms in the retirement-age sample have lower average announcement returns and takeover premiums. The takeover premium from trading day -20 before the announcement date to the final offer price is $26 \%$ for the above-65 sample, compared to $33 \%$ for other firms (medians are 23\% and 30\%, respectively). Not surprisingly, retirement-age CEOs are on average older and have longer tenures. They are also more likely to be classified as founders. The firms in the retirement-age sample are, on average, smaller than other firms:

\footnotetext{
${ }^{11}$ If a fiscal year is a firm's final year on Compustat, then the acquisition indicator is set to one if the firm receives a bid during that year or within the next fiscal year. This ensures that we include cases in which the bid announcement occurs after the end of the firm's last reported fiscal year.

${ }^{12}$ The sample sizes in the bid frequency analysis and the takeover premium analysis are slightly different. The reason is that the unit of analysis in the bid frequency regressions is a CEO-year, while it is an individual takeover bid in the takeover premium regressions.
} 
the mean market value of equity is $\$ 2.1$ billion, vs. $\$ 3.8$ billion for firms with younger CEOs (the medians are $\$ 0.8$ billion and $\$ 1.0$ billion, respectively). None of the other differences between the two samples are statistically significant.

\section{Retirement age and takeovers}

\subsection{Bid frequencies}

This section examines the effect of CEO age on the likelihood of receiving an acquisition bid. Using the panel data set described in Section 3.2, we estimate a probit model with the dependent variable equal to one if a firm becomes the target of a bid in a given fiscal year. The results are presented in Table 2. The left panel counts all takeover bids, including those for partial equity stakes. The right panel counts only control bids, i.e., bids for at least $50 \%$ of the target's equity. ${ }^{13}$

The main variable of interest is the retirement-age indicator RET_AGE, which is equal to one if the CEO is older than 65 at the time of the bid. ${ }^{14}$ All regressions in Table 2 show that the likelihood of receiving a bid increases sharply at age 65. The effect appears to be discrete, with no gradual increase as CEOs approach retirement age. For example, in the first column of Table 2, the likelihood of a bid increases from $7 \%$ to $10 \%$ per year (a $43 \%$ increase in the odds) as we move from the below-65 to the above-65 sample. The increase is significant at the $1 \%$ level, and the effect is similar when we limit the analysis to successful bids. When only control bids are considered (the right panel of Table 2), the bid probability increases from $4 \%$ to $6 \%$ p. a. for retirement-age CEOs (a $50 \%$ increase in the odds). Depending on the specification, the t-statistics on the retirement-age dummy range from 1.92 to 2.79 for all control bids, and from 1.74 and 2.88 for successful control bids.

The regressions control separately and linearly for CEO age, though age itself should be correlated with CEOs' private mergers costs. Specifically, private merger costs should decline as CEOs approach retirement (independently of any additional age-65 effect), though the relation may be confounded by correlated factors. For example, younger CEOs might have better career opportunities outside their firms and, consequently, view mergers as less

\footnotetext{
${ }^{13}$ Section 5 analyses partial acquisitions in more detail.

${ }^{14}$ Section 4.3 shows sensitivity analyses with alternative definitions of the retirement age.
} 
costly. Younger CEOs might also lead more dynamic firms and therefore experience a more active takeover market.

Table 2 allows for possible non-linearities in the age-bid-frequency relation in two ways. First, we replace CEO age with dummy variables for CEOs in five-year age groups, leaving out the 56-60 group, which contains the median CEO age. Second, we include age-squared in the regressions in addition to age itself. These specifications provide further support for a discrete retirement-age effect: the coefficient on RET_AGE remains positive and significant in all regressions. The age-squared term is negative but not significant, and including it tends to strengthen the discrete retirement-age effect. The regressions with 5-year age dummies show that successful takeover bids are 50-60\% more likely for firms with retirement-age CEOs than for firms with CEOs aged 56-60, and the difference is always significant at better than the $1 \%$ level. In three out of four specifications, the bid frequency is slightly (and insignificantly) lower in the 61-65 group than in the 56-60 group, implying that there is no gradual increase in bid frequencies as CEOs approach retirement age. Instead, bid frequencies increase abruptly as CEOs pass age 65.

Most of the other age indicator variables are not statistically significant, with the exception of the negative coefficient on AGE $<51$ in the last column of Table 2. This result is consistent with higher private merger costs for the youngest CEOs, though it is not robust across different specifications. Turning to other control variables, the regressions show that bids are significantly less likely for CEOs with longer tenures, for older and larger firms, and for firms that performed well in the past, based on both accounting returns and stock returns. There is also some evidence that founders are less likely to receive bids, though this result is not significant for control bids.

\subsection{Bid success probabilities}

Table 2 shows similar retirement-age effects on the frequencies of all takeover bids and the frequencies of successful takeover bids. This suggests that target CEO age has at most a small effect on the probability that a bid will result in a successful acquisition. We confirm this directly using a probit model for bid success as a function of target CEO age and a range of firm and bid characteristics, matching those in Table 2. The panel contains only firm-years in which the firm receives a control bid (i.e., in which the dependent variable in columns 7-9 of Table 2 equals one). The dependent variable in the probit model is set to one if the target 
firm is actually acquired. The estimated effect of the retirement-age indicator on the odds of bid success is positive but statistically insignificant (t-statistic of 1.16) in a regression with five-year CEO age dummies, and it is negative and insignificant (t-statistic of -0.25) in a regression with CEO age and age-squared as control variables. These results are not tabulated and are available from the authors.

The result that retirement-age CEOs have large positive effects on the probability of receiving a takeover bid, but at most small effects on the probability of bid success (conditional on a bid), is not surprising. Given the large time, effort, and monetary costs of takeover bidding, acquirers should only initiate bids if the probability of success is high enough to compensate for the costs. There is no obvious reason to expect acquirers to take more risk in the bid initiation just because the target CEO is of retirement age.

\subsection{Announcement returns and takeover premiums}

We next examine the implications of target CEOs' retirement preferences for acquisition announcement returns and premiums. Three potential mechanisms suggest weaker target announcement returns in the above-65 sample. First, outside investors might view takeovers of firms with retirement-age CEOs as more likely, therefore driving up target valuations already ahead of the bid. Second, target CEOs who are ready to retire might bargain less hard and therefore capture a smaller fraction of the synergies for their firms. Finally, takeovers with retirement-age CEOs should on average generate lower synergies for the bidder and target combined. Lower synergies follow directly from the idea that retirement-age CEOs suffer lower personal costs of being acquired. We expect that a target CEO's attitude to a bid is determined by both her private costs and by the expected effect of the takeover on target shareholder wealth. CEOs of retirement age, who have lower private merger costs, should allow more mergers to go through, which is what we document in the previous section. Moreover, these additional transactions done by retirement-age CEOs should, on average, generate lower gains for target shareholders. This argument is illustrated in Figure A in the Appendix.

Table 3 shows that announcement returns and takeover premiums are in fact substantially lower for target firms with retirement-age CEOs. The sample, described in Section 3.3, consists of 724 completed takeover deals. The dependent variables in the first four regressions are the bid announcement returns $\operatorname{RET}(-3,1)$ and $\operatorname{RET}(-20,1)$, defined as the 
cumulative industry-adjusted target stock returns from trading day -3 or -20 to day +1 after the announcement date. The dependent variable in the last two columns is the takeover premium, computed from the closing price on trading day -20 to the final offer and adjusted for the matched industry return over the same period. We use the 49 Fama-French equalweighted industry returns for the industry adjustment.

Controlling for CEO, firm, and deal characteristics, the Table 3 regressions show that targets with retirement-age CEOs have significantly lower announcement returns and takeover premiums than targets with younger CEOs. The differences are economically large. For example, column 4 shows that RET(-20,1) is 10 percentage points lower for retirementage CEOs than for younger CEOs (with a t-statistic of -2.87), a large effect compared to the average announcement return of 22\%. Similarly, the takeover premium is 10 percentage points lower in the retirement-age sample (with a t-statistic of -2.48), again a large difference compared to the average premium of $32 \%$.

Beyond these large retirement-age effects, there is no evidence that CEO age itself is associated with either takeover premiums or announcement returns. Similar to the bid frequency analysis in Table 2, we control for CEO age linearly (columns 1,4,7), using 5-year age-range indicators (columns 2,5,8), and including both age and age-squared (columns 3,6,9). These additional age controls are always insignificant, and the coefficients on RET_AGE are almost unaffected. The statistical significance of the RET_AGE effect is lowest when age-squared is included, but the weakest t-statistic is still $-1.67(\mathrm{p}=0.11)$. The evidence suggests that announcement returns and premiums change abruptly when target CEOs reach retirement age, with no evidence for a gradual effect as CEOs approach age 65.

Next, we attempt to determine why target announcement returns and premiums are lower for retirement-age CEOs. To preview, we find no evidence that targets with retirement-age CEOs have larger price run-ups before the first bid announcement, and no evidence that retirement-age CEOs bargain less hard. We tentatively conclude that retirement-age CEOs seem to agree to deals with lower synergies and lower gains for their shareholders, consistent with the idea that retirement-age CEOs have lower personal merger costs.

\subsubsection{Price run-ups before the first bid announcement}

Fig. 2 plots the cumulative industry-adjusted stock returns around the first bid announcement date for the above- and below-65 groups. The figure confirms that firms with 
retirement-age CEOs exhibit lower announcement returns, though the difference is somewhat smaller than the estimates from the multivariate analysis in Table 3. The pre-announcement price run-up is small and starts after day -20, consistent with Betton et al. (2008), who examine a similar sample. Importantly, the run-up is similar for the retirement-age and the below-retirement-age samples, suggesting no difference in takeover rumors or information leakage leading up to the merger announcements. It is, however, difficult to rule out that merger expectations formed in the more distant past differ between the two samples, and we provide a comparison of long-term pre-announcement returns in Section 4.6.1. The result there is again that the prior returns of retirement-age CEOs in the one to five years before the bid announcement are no higher than those of younger CEOs.

\subsubsection{Acquirer gains}

Table 4 tests the idea that retirement-age CEOs bargain less hard and, as a result, leave more of the takeover gains to acquirers. Because of the need to observe acquirer stock returns, the sample consists of 469 acquisitions by publicly-held acquirers. The dependent variables are the acquirer announcement returns $\operatorname{RET}(-3,1)$ and $\operatorname{RET}(-20,1)$, defined as the acquirers' cumulative industry-adjusted stock returns over trading days -3 or -20 through +1 around the announcement date. The regressions use the same independent variables as the analysis of target announcement returns in Table 3, and, in addition, include the acquirer's book-to-market ratio and the relative size of the target.

Table 4 shows no evidence that acquirer announcement returns differ when targets have a retirement-age CEO. The coefficient on the retirement-age indicator is positive but economically small and statistically insignificant (with t-statistics ranging from 0.17 to 1.37). There is also little evidence that target CEO age itself is related to acquirer returns.

To account for the fact that acquirers are frequently much larger than targets, we also test whether the age of the target CEO affects the fraction of the total synergies captured by the acquirer. Following methodologies developed by Bradley, Desai, and Kim (1988), Ahern (2010), and Harford, Jenter, and Li (2011), total synergies are defined as the combined changes in bidder and target market values around the bid announcements. In untabulated regressions, we find no evidence that acquirers manage to capture a larger fraction of the combined synergies when the target CEO is of retirement age. This suggests that retirement- 
age CEOs bargain no less hard than younger CEOs, and that the lower target gains for retirement-age CEOs are due to lower overall synergies.

\subsection{Is it really an age-65 effect?}

The literature on workers' retirement choices suggests that retirement preferences change at age 65, and this is what our tests have assumed. In this section, we repeat the prior analyses after shifting the cutoff by one or two years in either direction. Consistent with social norms or customs causing a sharp change in preferences at age 65, and also consistent with the observed spike in CEO departures at age 65, the results become weaker when we use alternative thresholds. ${ }^{15}$

First, we repeat the bid frequency regressions in Table 2 that use control bids as the dependent variable (column 8). When the cutoffs for retirement age are 63, 64, 65, 66, and 67, we obtain marginal effects of RET_AGE on bid frequencies of 1.0\%. 1.2\%, 1.9\%, 1.2\%, and $1.2 \%$ (with corresponding t-statistics of 1.81, 1.99, 2.79, 1.53, and 1.44). The lower coefficients for age-cutoffs above 65 suggest that, within the retirement-age sample, bid frequencies are highest for CEOs who just reached retirement age and then subsequently decline. Next, we re-estimate the takeover premium regressions from Table 3, column 8, for the same definitions of retirement age. The effects of RET_AGE on premiums are -0.05, $0.09,-0.11,-0.11$, and -0.12 (with t-statistics of $-1.47,-2.54,-2.66,-2.45$, and -2.06 ). The premium regressions show less sensitivity to the definition of retirement age, especially to upwards shifts, suggesting that premiums remain low even for the oldest CEOs.

\subsection{Alternative (and complementary) explanations for the retirement-age effect}

This paper has so far documented a sizeable increase in takeover activity and a large decline in takeover premiums when target CEOs are above age 65. These results support the hypothesis that target CEOs' retirement preferences affect takeover decisions. In this section, we consider other explanations for these findings, and show how the retirement-age effect varies across firms. The common theme across the alternative explanations is that CEOs who stay in office beyond age 65 (or their firms) might be different from younger CEOs (or their firms). In turn, it might be these differences, rather than retirement-age itself, that is causing

\footnotetext{
${ }^{15}$ This section describes only regressions with 5-year age dummies as controls for CEO age (rather than $\mathrm{CEO}$ age and age squared). These regressions compare the retirement-age group to a benchmark sample of CEOs aged 55-60. The alternative specifications generate similar patterns.
} 
the higher bid frequencies and lower takeover premiums. We consider four such "omitted variable" stories in this section.

\subsubsection{Disciplinary takeovers}

Firms with CEOs above age 65 might experience more disciplinary takeovers. Staying in office beyond retirement age might signal that the CEO is entrenched and unwilling to retire voluntarily. If, in addition, performance is bad, this might trigger a disciplinary takeover.

Because disciplinary takeovers are usually preceded by bad performance, we test this hypothesis by comparing the long-run pre-bid stock price performance for takeover targets in the above- and below-65 samples. A higher frequency of disciplinary takeovers for retirement-age CEOs should be reflected in worse prior performance. Table 5 shows regressions of pre-bid stock returns on the retirement-age indicator and other target CEO and firm characteristics. In the first two columns, the dependent variable is the average industryadjusted monthly stock return over the year starting in month -15 before the first bid announcement and ending in month -4. If a CEO has been in office for less than 15 months, then returns are measured from the CEO's start on the job. Columns 2 and 3 measure returns starting 3 years before month -4 , and columns 4 and 5 starting from the beginning of the CEO's tenure. To conserve on space, only coefficients and t-statistics for the CEO age variables are reported. In addition, the regressions control for the target firm's book-tomarket ratio, its market value of equity, firm age, and the CEO's tenure and percentage share ownership.

The effect of RET_AGE on returns is not statistically significant in any of the regressions, and is in fact positive in five out of six specifications. Thus, there is no evidence that retirement-age CEOs perform worse than younger target CEOs over any of the examined horizons. As an additional robustness test, the first column of Table 6 shows a probit regression relating the probability of receiving a takeover bid to the RET_AGE indicator and an interaction term of RET_AGE with stock returns over the prior year. The interaction term is small and not statistically significant, with a t-statistic of -0.05 . This indicates that bids for firms led by retirement-age CEOs are no more sensitive to prior performance than bids for 
other firms. Overall, the analysis of pre-bid performance provides no support for disciplinary takeovers as an explanation for the retirement age-effect. ${ }^{16}$

\subsubsection{Firms with succession problems}

CEOs who remain in office after reaching age 65 may do so because their firms have difficulties finding a successor. Merging with another firm can solve a CEO succession problem by giving the target firm access to the acquirer's managers. If this motive for mergers is important, then it might explain a higher frequency of bids for firms with post-65 CEOs. The implication of this hypothesis for announcement returns and takeover premiums is less clear. If solving succession problems is an added benefit of mergers (in addition to other synergies), this added benefit should be reflected in higher average premiums and announcement returns in the post-65 sample, which contradicts our results. It is possible, however, that takeovers that are motivated by succession problems generate fewer overall synergies than other takeovers and therefore also lower announcement returns.

To explore whether succession problems can explain our results, we use several methods to identify firms for which replacing a retiring CEO may be more difficult. The first approach identifies industries in which CEO talent is scarce as industries with unusually high CEO pay. The measure of abnormal industry-average CEO pay (Industry Pay) is the loadings on industry dummies from a regression of CEO pay on firm characteristics and 2-digit SIC industry indicators. ${ }^{17}$ To test whether target CEO age matters more in high-paying industries, column 2 of Table 6 regresses the probability of receiving a takeover bid on the retirementage indicator and the interaction between RET_AGE and Industry pay. The interaction effect is positive but not statistically significant (the t-statistics are 1.14 and 1.37 for the interaction coefficient and the interaction effect, respectively). The coefficient on RET_AGE itself, which now captures the effect of having a retirement-age CEO in an industry with average pay, remains large and significant.

\footnotetext{
${ }^{16}$ It is interesting to note that target CEOs below age 55 appear to have better stock return performance before receiving takeover bids than older CEOs. This is consistent with the notion that target firms with older CEOs are more likely to be acquired for disciplinary reasons. However, because there are no significant differences between CEOs aged 56-60, 60-65, and the retirement-age CEOs, differences in prior performance cannot explain why mergers become abruptly more frequent at age 65 .

${ }^{17}$ Total annual CEO compensation is regressed on the log market value of equity, the book-to-market ratio, the ratio of R\&D to assets, the ratio of PP\&E and inventory to assets, book leverage, sales growth, ROA, firm age, and industry dummies.
} 
Next, we try to identify extraordinarily skilled individual CEOs who may be difficult to replace. The departure of a highly-skilled CEO can trigger a succession problem if the board insists on a successor who matches the predecessor's ability. The attempt to match ability can be optimal if the firm needs a highly-skilled CEO, or it might reflect board irrationality. The third column in Table 6 replaces Industry pay with the individual-specific excess CEO pay averaged over the three years preceding the bid (CEO pay). ${ }^{18}$ The coefficient on this interaction term is negative and not significant, suggesting that the retirement-age effect is no stronger for highly-paid CEOs. The fourth column in Table 6 replaces CEO pay with CEO performance, the average industry-adjusted stock price performance over the CEO's tenure. The interaction term is again negative and insignificant, suggesting that the retirement-age effect is also no stronger for CEOs with better prior performance.

Finally, boards might find it more difficult to replace founder CEOs and therefore opt for a company sale when the founder retires. In the same vein, founders themselves might prefer selling their firm to passing it on to a successor, for either psychological or liquidity reasons. ${ }^{19}$ The fifth column of Table 6 tests whether the retirement-age effect on the probability of receiving a bid is stronger for founder CEOs. The interaction term between RET_AGE and founder is negative and insignificant, and the effect of RET_AGE itself is strengthened. Hence, if anything, founders seem to be slightly less likely to sell their firms when reaching retirement age.

Overall, the evidence in Table 6 provides little support for the idea that the effect of CEO age on takeover frequencies is caused by target firms with succession problems. However, we cannot rule out that succession problems contribute to the retirement-age effect in at least some firms.

\subsubsection{Interim CEOs}

Firms with leadership or performance problems sometimes hire interim CEOs whose task it is to find a successor or to sell the firm. Anecdotally, interim CEOs are often retired CEOs from the same or some other firm, and, as a result, relatively old. Such interim CEOs might be responsible for the result that acquisitions are more frequent in the retirement-age sample.

\footnotetext{
${ }^{18}$ Excess pay is estimated as the residual from the CEO pay regression described in the previous footnote.

${ }^{19}$ Section 4.5.4 examines the liquidity motive for selling the firm at the CEO's retirement in detail and finds no empirical evidence for it.
} 
All results reported in this paper are based on samples without interim CEOs. We search newspaper articles and other sources to identify CEOs who have been described in the press as interim at the time of their hiring. There are 144 interim CEOs that we exclude from the data. In untabulated regressions, we use the larger panel that includes the 144 interim CEOs to test whether the retirement-age effect on mergers is stronger for interim CEOs. Similar to Table 6, the analysis regresses the probability of receiving a takeover bid on the retirementage indicator and an interaction between RET_AGE and a dummy for interim CEOs. Interestingly, the coefficient on the interim dummy itself is positive and significant, but the coefficient on the interaction term of RET_AGE with the interim dummy is negative and significant (t-statistic of -2.05). Hence, as expected, interim CEOs are more likely to receive merger bids than other CEOs, but this effect is weaker among CEOs of retirement age.

\subsubsection{CEO illiquidity}

Acquisitions frequently allow target CEOs to cash out their illiquid stock and option holdings in their firm. Cai and Vijh (2007) find evidence that CEOs with illiquid holdings are more likely to receive takeover bids and less likely to resist bids. Even though there is no reason to expect that CEOs' illiquidity problems increase abruptly at age 65, illiquidity can explain why CEOs who are ready to retire might prefer an acquisition to a CEO succession.

To test whether the retirement-age effect on mergers is stronger for CEOs with larger stock and option holdings, we define two measures of CEO illiquidity: the natural logarithm of the value of CEO stock and option holdings (Holdings), and the ratio of the value of stock and option holdings to the CEO's total prior compensation (Illiquid). Total prior compensation is estimated as the median annual compensation received by the CEO during her tenure multiplied by the number of years in office (the median is based on years available on ExecuComp only). Columns 6 and 7 of Table 6 regress the probability of receiving a takeover bid on the retirement-age indicator and interactions between RET_AGE and the two illiquidity measures. The interaction effects are small and insignificant, and the effect of RET_AGE itself is unaffected. This suggests that the retirement-age effect is no stronger for CEOs with larger equity exposures to their firms.

Finally, we note that CEOs' fractional ownership, measured as stock holdings divided by total shares outstanding, strengthens the retirement-age effect. The final column of Table 6 shows that the positive effect of RET_AGE on the probability of receiving a takeover bid is 
significantly stronger for CEOs with larger percentage stakes. CEOs’ percentage ownership, even though arguably less useful as a measure of illiquidity, has been used in the literature as a measure of CEO power (e.g., Stulz (1988)). This last result therefore suggests that more powerful CEOs’ retirement preferences have larger effects on firm behavior.

\subsection{Do the additional deals accepted by retirement-age CEOs create value?}

The evidence in this paper supports the idea that above-65 CEOs have lower personal merger costs and are therefore better aligned with shareholders. However, an alternative interpretation of our results is that it is younger CEOs who act in the best interest of shareholders, and that retirement-age CEOs are too eager to give up control.

The balance of evidence from prior studies speaks against this possibility. More power for target managers vis-à-vis shareholders, due to larger equity stakes, insider-dominated boards, poison pills, or a lack of outside blockholders, is associated with fewer acquisitions in the data (Mikkelson and Partch (1989), Shivdasani (1993), Song and Walkling (1993), North (2001)). This suggests that target managers, most of whom are younger than 65, are more reluctant than shareholders to sell their firms.

Under strong assumptions, it is possible to estimate the value created for target shareholders through the additional deals done by retirement-age CEOs. Specifically, one needs to assume that, with the exception of these additional mergers, retirement-age CEOs do exactly the same deals as younger CEOs. With this assumption, knowing the value created by each of the two age groups, one can deduce the value attributable to the additional deals.

This calculation shows that, on average, the additional deals done by retirement-age CEOs create positive value for target shareholders. For example, using estimates from column 8 of Table 3, the takeover premiums are 25\% for retirement-age CEOs and 36\% for younger CEOs. By assumption, this difference is caused entirely by the additional deals done by retirement-age CEOs. Based on the bid frequencies estimated in Table 2 (column 11), retirement-age CEOs do 4.6/2.9 = 59\% more deals than younger CEOs. ${ }^{20}$ For these additional deals to lower the average premium from 36 to $25 \%$, the additional deals must be done at an

\footnotetext{
${ }^{20}$ Both the turnover premiums and bid frequencies are calculated at the means of all control variables.
} 
average premium of $7 \%$. This positive but moderate number is consistent with the hypothesis that retirement-age CEOs accept marginal deals that younger CEOs would have rejected. ${ }^{21}$

\section{$5 \quad$ Retirement age and partial acquisitions}

This paper has found that takeover bids are more frequent when the target CEO is above 65. Table 2 shows that this result obtains independently of whether partial acquisition bids are included or excluded from the sample. This section explores partial acquisitions, i.e. bids in which the acquirer seeks to own less than $50 \%$ of the target's equity, in more detail.

The main hypothesis of this paper is that retirement-age CEOs face lower private costs of being acquired and are therefore less likely to resist takeover bids. There are several reasons why the same mechanism could cause more frequent bids for partial equity stakes. First, a more active takeover market for firms with retirement-age CEOs might induce more information-based position-taking by merger arbitrageurs, as well as more toehold purchases by potential acquirers. Second, activist investors might view an impending CEO change as an opportunity to influence the firm, making block ownership more valuable. For example, if outgoing CEOs care less about the rents extracted by future managers, then they might be more receptive to strengthening corporate governance at the firm.

To explore these ideas we proceed in two steps. First, Section 5.1 verifies that the frequency of partial acquisition bids is indeed higher for retirement-age CEOs. We also examine whether the acquisition mechanisms used differ for target CEOs above and below age 65, which should provide some indication of the deals' purpose. Second, Section 5.2 examines press reports for a subset of 39 partial acquisitions in the retirement-age sample for which we have complete SDC data. The goal of this analysis is a deeper understanding of the motives behind these transactions.

\subsection{Frequency of partial acquisitions}

Table 7 shows descriptive statistics for the 1,184 partial acquisition bids in our data. In the retirement-age sample, acquirers own on average $5.0 \%$ of the target's equity prior to the deal and seek to own $11.6 \%$ after the transaction (compared to $3.2 \%$ and $11.0 \%$ for younger

\footnotetext{
${ }^{21}$ This analysis requires that takeover premiums are good estimates of value creation and are not contaminated by market expectations. If investors anticipate more takeovers of firms led by retirement-age CEOs, then the estimate of value creation in the retirement-age sample will be too low, which makes it even more likely that the additional deals done by retirement-age CEO create value for target shareholders.
} 
CEOs, respectively). Sixty-four percent of the partial acquisitions with retirement-age CEOs are open market purchases and 28\% are negotiated block trades (the remaining deals are not classified). This compares to $53 \%$ and $41 \%$, respectively, for firms with younger CEOs. Out of the 88 deals in the retirement-age sample, 25 are block purchases, and only 9 of those deals have offer prices available on SDC. Tentative evidence based on this small sample suggests that block premiums, measured from the closing price on the day of the bid announcement to the final offer price, are higher in the retirement-age sample: the mean premium is $27 \%$ vs. $9 \%$ for younger CEOs, and the median is $14 \%$ vs. $2 \%$. This pattern supports the conjecture that the private benefits from block ownership are higher in the retirement-age sample. ${ }^{22}$

Turning to the bid frequency regressions in Table 8, the data show that partial acquisition bids are significantly more likely for retirement-age CEOs, echoing the results for control bids. The likelihood of receiving a bid in a year in which the CEO is older than 65 is 5.8\%, compared to only $2.8 \%$ for other years (column 1 ). The effect is significant in all three bid size categories considered $(0-10 \%, 10-20 \%$, and $20-50 \%$ of target equity), though it appears stronger for larger bids.

The last two columns of Table 8 test whether the partial acquisition mechanisms used differ between target CEOs above and below age 65. Interestingly, this does not appear to be the case, with a similar retirement-age effect present for both open market purchases and negotiated block trades. Activist investors seeking to increase their voting power could use both types of acquisition strategies, but investors trading on information or acquiring toeholds should be more likely to trade in the open market. This suggests that activist investors are one reason for the higher frequency of partial acquisitions of firms led by retirement-age CEOs.

\subsection{What motivates partial acquisitions in the retirement-age sample?}

To better understand the motives behind partial acquisitions in the retirement-age sample, this section examines news articles about these transactions. The analysis is limited to 39 deals (out of a total of 88) for which we have all relevant variables, including the offer price from SDC. A search of all news sources available in the Factiva database provides

\footnotetext{
${ }^{22}$ See Barclay and Holderness (1989 and 1991) for a discussion of block premiums as measures of private benefits of control.
} 
information about 33 out of the 39 deals. After reviewing the articles, we divide the transactions into three broad categories: (1) investment deals, in which the acquirer appears to be a financial investor (this group is further subdivided into passive and active deals); (2) synergistic deals, in which the acquirer is a firm active in the same or a related industry as the target firm; and finally (3) other deals that do not fit the previous categories. Out of the 33 deals for which we can find press reports, 23 are investment deals, six are synergistic deals, and five are classified as "other". 23

Most investment deals in the sample (17 out of 23) appear passive, in the sense that there is no public record of blockholder activism in the target firm. In a typical passive deal, a purchaser acquires the block in a series of open-market transactions. In many cases, the purchaser states that it has "no extraordinary plans for the company" and that the acquisition is for "investment purposes" only. Taking these statements at face value, passive deals seem to be bets on a rise in the target's stock price. Such bets may be more common in the retirement-age sample because of anticipated takeover bids, or because of other valueenhancing changes expected at the time of CEO turnover. We cannot rule out, however, that in some cases the blockholder's intention to become active in the firm is not disclosed, so that deals we classify as passive may in fact be active.

In a typical active deal, the acquirer announces plans to influence the policy of the target firm. Interestingly, in four out of the six active cases, there is an indication in the press that the target firm might (or should) be acquired. ${ }^{24}$ One example is a block acquisition of shares in Helene Curtis Industries by Shamrock Holdings announced in May of 1994. In connection with the deal, "Shamrock ... is asking Helene Curtis to consider a sale of the company or increase accountability of its board and management to its public shareholders." ${ }^{25}$ In a different example, in October 1994 and September 1995, an investor group appears to be acquiring a toehold in Hilton Hotels Corp. A related press report states that "At age 66, Chairman and CEO Barron Hilton is widely viewed - rightly or wrongly - as open to a deal

\footnotetext{
${ }^{23}$ The "other" deals are: (1) a private placement to a group of investors (all other purchases by "a group of investors" in the sample are open-market transactions); (2) a purchase of a company's stock by its pension fund; (3) a complete takeover misclassified by SDC as a partial acquisition; (4) a partial acquisition of the target's class B shares by a company that already has voting control of the target; and (5) a bailout by the U.S. Treasury Department.

${ }^{24}$ Greenwood and Schor (2009) show that the positive returns of activist shareholders are largely explained by their ability to force target firms into takeovers.

${ }^{25}$ Dow Jones Newswires, January 17, 1996.
} 
at the right price.” ${ }^{26}$ These examples are consistent with our prediction that firms with retirement-age CEOs are attractive takeover targets.

Six of the partial acquisitions fall into the "synergistic" category. In a typical deal of this type, the target and the acquirer are from the same or a related industry, and they announce plans to form a joint venture or a strategic alliance. For example, in 1992, Corimon International states that the company initiated an alliance with the target firm, Growth Group Inc., "to achieve critical mass in the world paints industry", and to gain "access to advanced technology and strengthen ... export potential." ${ }^{27}$ One article suggests that the Corimon deal is an example of a broader trend in which partial acquisitions replace the "mega-M\&A deals of the 1980s" and offer companies a cheaper way to "gain access to new technology and markets”. To support its claim, the article points out that with a $26 \%$ stake, Corimon will be the largest shareholder in Growth Group and will be able to exercise control.

The limited evidence on partial acquisitions presented in this section reinforces the conclusion that retirement-age CEOs are more open to doing deals. The majority of the partial bids in the retirement-age sample appear to be passive bets on an increase in the target's stock price, possibly motivated by an expectation of a future takeover of the target. Other partial acquisitions are by activist investors who explicitly push for the sale of the target. The remaining partial acquisitions seem directly aimed at gaining effective control of the target through a controlling minority stake. Finding that such deals are more frequent when the target CEO is of retirement age supports the hypothesis that CEOs' retirement preferences impact firm behavior.

\section{Conclusions}

This paper explores the impact of target CEOs' retirement preferences on the probability, the pricing, and the outcomes of takeover bids. Most target CEOs' careers suffer when their firms are acquired. If incentive pay does not fully compensate CEOs for their private costs, then firms' takeover decisions are likely to be distorted. We examine this hypothesis using a novel test. We exploit the labor literature's observation that workers' propensity to retire increases discretely at the age of 65 . This pattern cannot be explained by the provisions of

\footnotetext{
${ }^{26}$ Personal Investing Financial, September 20, 1994. “Takeover talk hits Hilton Hotels” by Tom Petruno.

${ }^{27}$ Chemical Week, July 29, 1992. "Corimon buys a stake in Grow Group and forms an alliance" by Elizabeth S. Kiesche.
} 
social security, Medicare, or pension plans, and is often attributed to customs and social norms. We derive implications of this age-65 effect for CEOs' private merger costs, and, indirectly, for predicted merger patterns.

Consistent with the private merger costs hypothesis, the data show that acquisition bids and takeovers are substantially more frequent for target CEOs above age 65. The increase in takeover activity appears discretely at this age threshold, with no gradual increase as CEOs approach retirement age. We argue that this finding is a consequence of a discrete drop in private merger costs at age 65, caused by the same preference shift that also underlies the age-65 retirement effect. The data also show that takeover premiums and announcement returns are significantly lower for above-65 CEOs, indicating that the additional deals done by retirement-age CEOs create less shareholder value on average. Retirement-age CEOs seem to require smaller shareholder gains to approve of a merger, which is again consistent with lower private merger costs. Overall, our findings suggest that CEOs' retirement preferences have a significant impact on firms' takeover decisions and, ultimately, on shareholder value. 


\section{Appendix: The effects of target CEOs' private career costs on mergers}

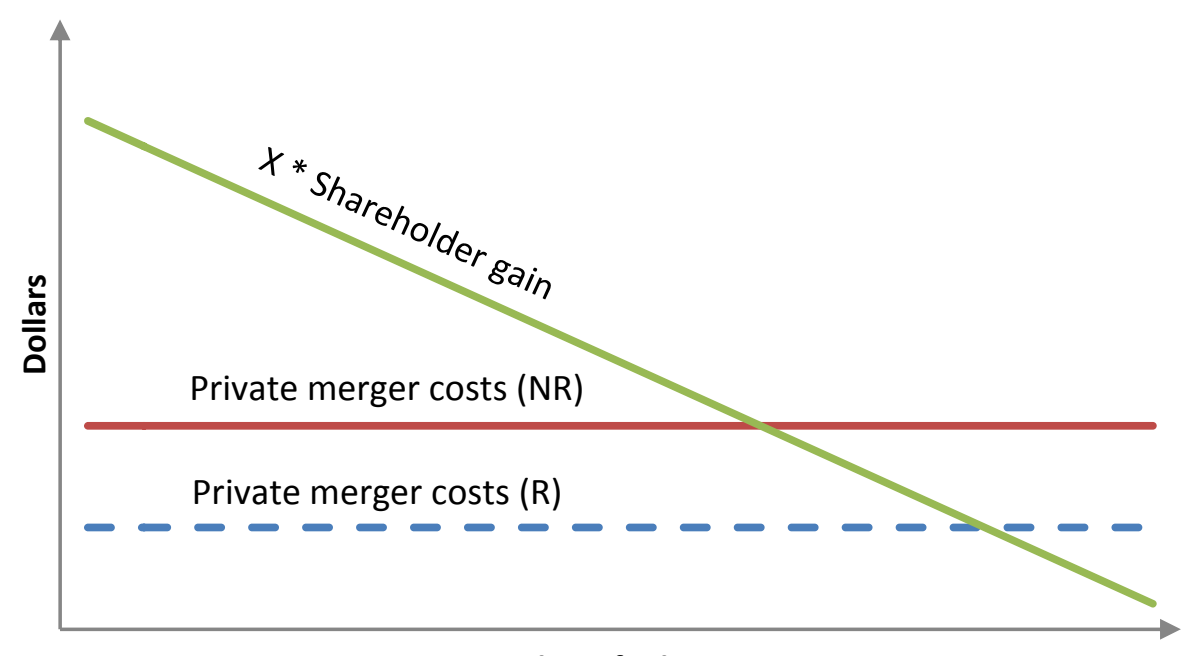

Number of takeovers

Fig. A: The effects of target CEOs' private career costs on mergers. This figure illustrates differences in merger patterns between the retirement-age sample (R) and the non-retirement-age sample (NR). Merger decisions are made by target CEOs. A target CEO cares about both her private merger costs (e.g., costs associated with losing her job) and about the effect of the merger on target shareholder wealth. In the diagram, the target CEO's gain from a merger equals $\mathrm{X}$ percent of the target shareholders' gains. The CEO accepts a merger proposal if her share of the shareholder gains exceeds her personal cost. By assumption, private merger costs are lower in the R sample than in the NR sample. This leads to a higher number of mergers, but also to lower average shareholder gains in the $\mathrm{R}$ sample. The latter result obtains because the incremental mergers accepted by CEOs in the R sample create lower shareholder gains than the mergers accepted by CEOs from both samples. 


\section{References}

Agrawal, Anup, and Ralph Walkling, 1994, Executive careers and compensation surrounding takeover bids, Journal of Finance 49, 985-1014.

Ahern, Kenneth, 2010, Bargaining power and industry dependence in mergers. Journal of Financial Economics, forthcoming.

Ai, Chunrong, and Edward C. Norton, 2003. Interaction terms in logit and probit models, Economics Letters 80, 123-129.

Ambrose, Brent W., and William L. Megginson, 1992. The role of asset structure, ownership structure, and takeover defenses in determining acquisition likelihood, Journal of Financial and Quantitative Analysis 27, 575-589.

Barclay, Michael J., and Clifford G. Holderness, 1989, Private benefits from control of public corporations, Journal of Financial Economics 25, 371-395.

Barclay, Michael J., and Clifford G. Holderness, 1991. Negotiated block trades and corporate control, Journal of Finance 46, 861-878.

Bargeron, Leonce L., Frederik P. Schlingemann, René M. Stulz, and Chad J. Zutter, 2010, Are acquisition premiums lower because of target CEOs' conflicts of interest? Working paper, University of Pittsburgh, The Ohio State University, NBER and ECGI.

Bebchuk, Lucian, Alma Cohen, and Charles C. Y. Wang, 2010, Golden parachutes and the wealth of shareholders, Working paper, Harvard Law School and NBER, Tel-Aviv University, and Stanford University.

Bertrand, Marianne, and Antoinette Schoar, Managing with style: The effect of managers on corporate policy, Quarterly Journal of Economics 188, 1169-1208.

Betton, Sandra, Espen B. Eckbo, and Karin S. Thorburn, 2008, Markup pricing revisited, Working paper, Concordia University, Quebec and Tuck School of Business.

Blau, David M., 1994, Labor force dynamics of older men. Econometrica 62, 117-156.

Bradley Michael, Anand Desai, and E. Han Kim, 1988, Synergistic gains from corporate acquisitions and their division between the stockholders of target and acquiring firms, Journal of Financial Economics 21, 3-40.

Burtless, Gary, 1986, Social security, unanticipated benefit increases, and the timing of retirement, Review of Economic Studies 53, 781-805.

Cai, Jie, and Anand M. Vijh, 2007, Incentive effects of stock and options holdings of target and acquirer CEOs, Journal of Finance 62, 1891-1933.

Cotter, James, and Marc Zenner, 1994, How managerial wealth affects the tender offer process, Journal of Financial Economics, 35, 63-97. 
Dechow, Patricia M., and Richard D. Sloan, 1991, Executive incentives and the horizon problem: an empirical investigation, Journal of Accounting and Economics 14, 51-89.

Datta, Sudip, Mai Iskandar-Datta, and Kartik Raman, 2001, Executive compensation and corporate diversification decisions, Journal of Finance 56, 2299-2336.

Denis, David J., Diane K. Denis, and Atulya Sarin, 1997, Agency problems, equity ownership, and corporate diversification, Journal of Finance 52, 135-160.

Eisfeldt, Andrea L., and Adriano A. Rampini, 2008, Managerial incentives, capital reallocation, and the business cycle, Journal of Financial Economics 87, 177-199.

Fich, Eliezer M., Anh L. Tran, and Ralph A. Walkling, 2010, On the importance of golden parachutes, Working paper, Drexel University.

Fich, Eliezer M., Jie Cai, and Anh L. Tran, 2011, Stock option grants to target CEOs during private merger negotiations, Journal of Financial Economics 101, 413-430.

Gibbons and Murphy, 1992, Optimal incentive contracts in the presence of career concerns: theory and evidence, Journal of Political Economy 100, 468-505.

Greenwood, Robin, and Michael Schor, 2009, Investor activism and takeovers, Journal of Financial Economics 92, 362-375.

Grinstein, Yaniv, and Paul Hribar, 2004, CEO compensation and incentives - Evidence from M\&A bonuses, Journal of Financial Economics 73, 119-143.

Harford, Jarrad, 2003, Takeover bids and target directors' incentives: The impact of a bid on directors' wealth and board seats, Journal of Financial Economics 69, 51-83.

Harford, Jarrad, Dirk Jenter, and Kai Li, 2011, Institutional cross-holdings and their effects on acquisition decisions, Journal of Financial Economics 99, 27-39.

Harris, Ellie G., 1990, Antitakeover measures, golden parachutes, and target firm shareholder welfare, Rand Journal of Economics 21, 614-625.

Hartzell, Jay, Eli Ofek, and David Yermack, 2004, What's in it for me? CEOs whose firms are acquired, Review of Financial Studies 17, 37-61.

Hausman, Jerry A., and David A. Wise, 1985, Social Security, Health Status, and Retirement, in D. Wise (ed.) Pensions, Labor, and Individual Choice. Chicago: University of Chicago Press, pp. 159-191.

Heitzman, Shane, 2011, Equity grants to target CEOs during deal negotiations, Journal of Financial Economics 102, 251-271.

Holmström Bengt, 1982, Managerial incentive schemes-a dynamic perspective, in Essays in economics and management in honour of Lars Wahlbeck, Helsinki: Swenska Handelshögkolan.

Hurd, Michael and Michael Boskin, 1981, The effect of social security on retirement in the early 1970s, Quarterly Journal of Economics 46, 767-790. 
Jensen, Michael C., 1986. Agency costs of free cash flow, corporate finance, and takeovers, American Economic Review 76, 323-329.

Jensen, Michael C., 1993, The modern industrial revolution, exit, and the failure of internal control systems, Journal of Finance 48, 831 - 880.

Knoeber, Charles R., 1986, Parachutes, shark repellents, and hostile tender offers, American Economic Review 76, 155-167.

Lewellen, Wilbur, Claudio Loderer, and Ahron Rosenfeld, 1985, Merger decisions and executive stock ownership in acquiring firms, Journal of Accounting and Economics 7, 209-231.

Li, Kai, and Jarrad Harford, 2007, Decoupling CEO wealth and firm performance: The case of acquiring CEOs, Journal of Finance, 62, 917-949

Lumsdaine, Robin L., James H. Stock, and David A. Wise, 1990, Efficient windows and labor force reduction, Journal of Public Economics 43, 131-159.

Lumsdaine, Robin L., James H. Stock, and David A. Wise, 1996, Why are retirement rates so high at age 65? in Advances in Economics of Aging (NBER) edited by David A. Wise.

Martin, Kenneth, and John McConnell, 1991, Corporate performance, corporate takeovers, and management turnover, Journal of Finance 46, 671-687.

Mikkelson, Waine H., and Megan M. Partch, 1989, Managers' voting rights and corporate control, Journal of Financial Economics 25, 263-290.

Moeller, Thomas, 2005, Let's make a deal! How shareholder control impacts merger payoffs, Journal of Financial Economics 76, 167-190.

Morck, Randall M., Andrei Shleifer, and Robert W. Vishny. 1988, Characteristics of targets of hostile and friendly takeovers, in: Alan J. Auerbach, Corporate takeovers: Causes and consequences, University of Chicago Press, Chicago, IL.

Murphy, Kevin J., and Jerold L. Zimmerman, 1993, Financial performance surrounding CEO turnover, Journal of Accounting and Economics 16, 273-315.

North, David S., 2001, The role of managerial incentives in corporate acquisitions: the 1990s evidence, Journal of Corporate Finance 7, 125-149.

Phelan, Christopher and John P. Rust, 1997, How Social Security and Medicare affect retirement behavior in a world of incomplete markets, Econometrica 65, 781-831.

Randall Morck, Andrei Shleifer and Robert W. Vishny, 1990, Do managerial objectives drive bad acquisitions? Journal of Finance 55, 31-48

Schwert, William G., 1996, Markup pricing in mergers and acquisitions, Journal of Financial Economics 41, 153-192.

Shivdasani, Anil, 1993, Board composition, ownership structure, and hostile takeovers, Journal of Accounting and Economics 16, 167-198. 
Song, Moon H., and Ralph A. Walkling, 1993. The impact of managerial ownership on acquisition attempts and target shareholder wealth, Journal of Financial and Quantitative Analysis 28, 439-457.

Stock, James H. and David A. Wise, 1990a, Pensions, the option value of work, and retirement, Econometrica, 58, 1151-1180.

Stock, James H. and David A. Wise, 1990b. The Pension inducement to retire: an option value analysis, in D. Wise (ed.) Issues in the Economics of Aging. Chicago: University of Chicago Press, 205-224.

Stulz, René, 1988, Managerial control of voting rights: Financing policies and the market for corporate control, Journal of Financial Economics 20, 25-54.

Stulz, René M., Ralph A. Walkling, and Moon H. Song, 1990. The distribution of target ownership and the division of gains in successful takeovers, Journal of Finance 45, 817-833.

Vancil, Richard, 1987, Passing the baton: Managing the process of CEO succession, Harvard Business School Press, Boston, MA.

Walkling, Ralph, and Michael Long, 1984, Agency theory, managerial welfare, and takeover bid resistance, Rand Journal of Economics 15, 54-68.

Weisbach, Michael S., 1995, CEO turnover and the firm's investment decisions, Journal of Financial Economics 37, 159-188.

Wulf, Julie, 2004, Do CEOs in mergers trade power for premium? Evidence from "mergers of equals,” The Journal of Law, Economics, and Organization 20, 60-101.

Wulf, Julie, and Harbir Singh, 2010, How do acquirers retain successful target CEOs? The role of governance, Management Science, forthcoming.

Yim, Soojin, 2010, The acquisitiveness of youth: CEO age and acquisition behavior, Working Paper, Goizueta Business School, Emory University. 


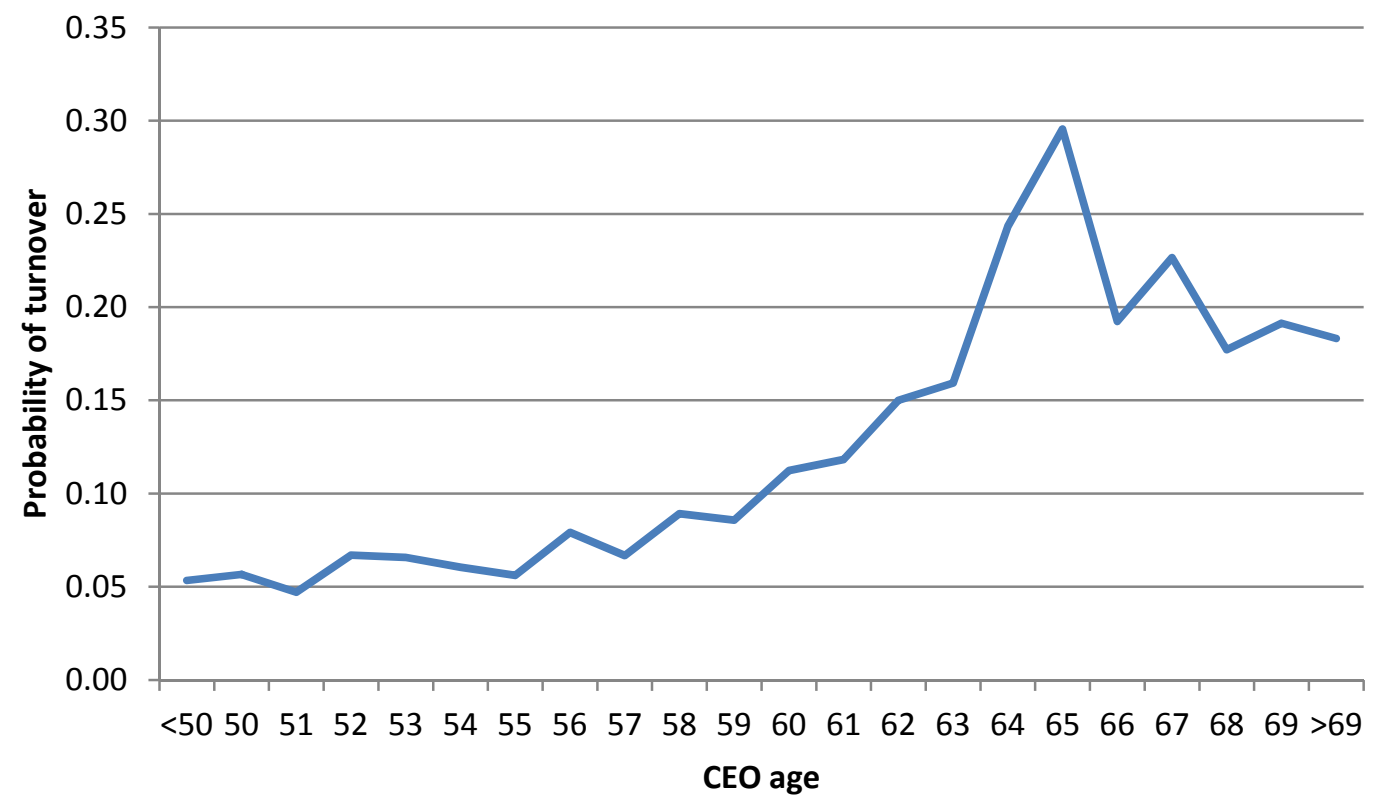

Fig. 1: Probability of CEO turnover as a function of CEO age. The figure shows the fraction of CEOs in office at age $t$ who leave office while of age t. The sample consists of 5,841 CEOs and 32,026 CEOyears from 1992 through 2008. 


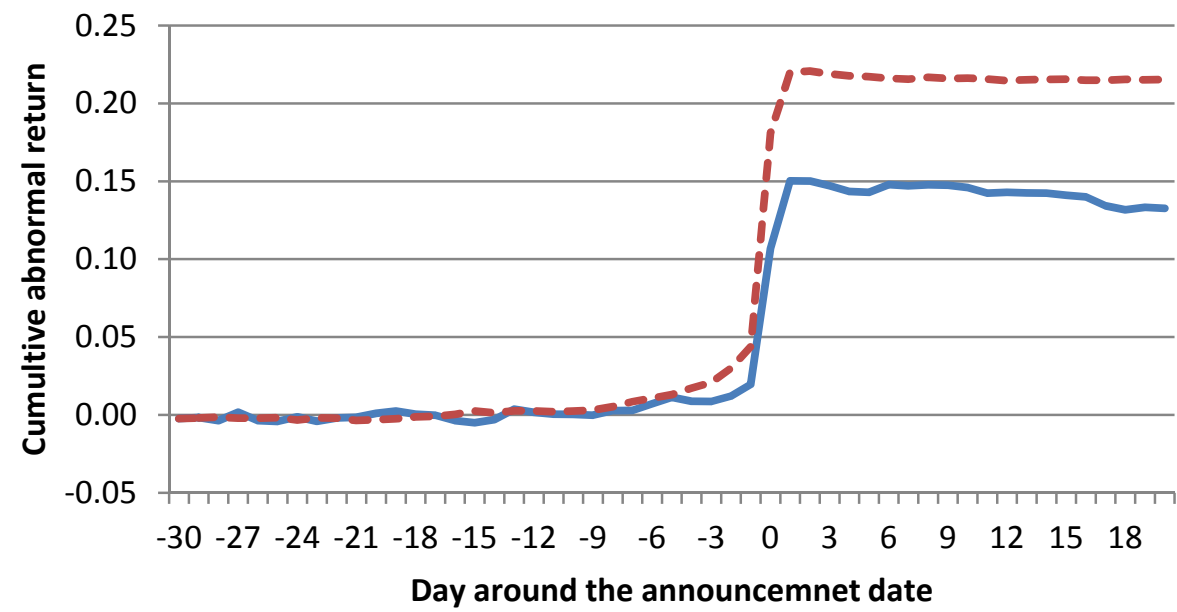

Retirement age CEOs $-\infty$ Other CEOs

Fig. 2: Stock returns around merger announcements. The figure shows the cumulative industryadjusted returns from trading day -30 to day +20 after the first bid. The figure uses a subset of 874 of the 928 completed control bids from 1992 through 2008 described in Table 1 for which return data is available. The returns are computed separately for 56 target firms with retirement-age CEOs (i.e., CEOs who are older than 65 at the time of the bid) and for 791 other target firms. 
Table 1: Descriptive statistics for the takeover sample. The sample consists of 928 completed takeovers from 1992 through 2008. The retirement-age cutoff is 65 years in the year of the bid announcement. RETURN (-x to 1 ) is the cumulative industry-adjusted daily return from day -x to day one after the first announcement date. PREMIUM (-20 to final) is defined as (final offer price - closing price on day -20) / (closing price on day -20), adjusted for the cumulative industry return over the same period. The takeover premiums are winsorized at the first and the $99^{\text {th }}$ percentile. CEO AGE is the age of the target CEO in the announcement year. TENURE is the number of years from the year the CEO takes office to the announcement year. FOUNDER is a dummy variable set to one for CEOs who are in office at least five years before the firm's first year on Compustat. OWNERSHIP is the number of shares owned by the target CEO in percent of shares outstanding. B/M, MVEQ, and ROA are the ratio of book value to market value of equity, the market value of equity (\$ billions), and the return on book assets of the target firm. These variables are measured in the last reported year prior to the takeover, or, for firms surviving the takeover on Compustat, for the year prior to the takeover announcement. PAST RETURN is the average monthly industry adjusted return from month -15 through -4 relative to the announcement month. CASH ONLY (STOCK ONLY) are dummy variables set to one if the SDC variable "consideration structure" is set to "cash only" (“shares”). HOSTILE (TENDER) is a dummy variable set to one if SDC classifies the bid as hostile (as a tender offer).

\begin{tabular}{|c|c|c|c|c|c|c|c|c|c|c|c|c|}
\hline & \multicolumn{6}{|c|}{ Target CEOs above the retirement-age threshold } & \multicolumn{6}{|c|}{ Other target CEOs } \\
\hline & Mean & Median & Std & Min & Max & $\mathrm{N}$ & Mean & Median & Std & Min & Max & $\mathrm{N}$ \\
\hline Return (-3 to 1$)$ & 0.14 & 0.10 & 0.19 & -0.36 & 0.68 & 56 & 0.20 & 0.17 & 0.20 & -0.44 & 1.27 & 791 \\
\hline Return (-20 to 1$)$ & 0.15 & 0.12 & 0.22 & -0.51 & 0.68 & 56 & 0.22 & 0.20 & 0.22 & -0.72 & 1.45 & 791 \\
\hline Premium (-20 to final) & 0.26 & 0.23 & 0.26 & -0.24 & 0.97 & 53 & 0.33 & 0.30 & 0.26 & -0.24 & 1.16 & 758 \\
\hline CEO age & 69.58 & 69.00 & 3.46 & 66.00 & 79.00 & 59 & 53.96 & 54.00 & 6.24 & 30.00 & 65.00 & 869 \\
\hline Tenure & 14.78 & 12.00 & 12.29 & 1.00 & 53.00 & 59 & 6.36 & 5.00 & 5.30 & 0.00 & 40.00 & 869 \\
\hline Founder & 0.20 & 0.00 & 0.41 & 0.00 & 1.00 & 59 & 0.05 & 0.00 & 0.22 & 0.00 & 1.00 & 859 \\
\hline Ownership & 5.55 & 2.61 & 6.75 & 0.00 & 26.74 & 58 & 1.61 & 0.26 & 4.06 & 0.00 & 45.82 & 824 \\
\hline $\mathrm{B} / \mathrm{M}$ & 0.66 & 0.51 & 0.48 & 0.05 & 2.08 & 58 & 0.56 & 0.50 & 0.38 & 0.05 & 2.08 & 847 \\
\hline MVEQ & 2,098 & 808 & 3,702 & 32 & 20,331 & 59 & 3,777 & 1,080 & 8,363 & 13 & 93,073 & 857 \\
\hline Firm age & 22.78 & 18.00 & 13.60 & 2.00 & 54.00 & 59 & 20.83 & 15.00 & 15.17 & 1.00 & 57.00 & 859 \\
\hline ROA & 0.04 & 0.03 & 0.09 & -0.22 & 0.30 & 59 & 0.04 & 0.04 & 0.09 & -0.37 & 0.34 & 847 \\
\hline Past return & -0.44 & -0.55 & 2.93 & -11.53 & 6.14 & 58 & -0.14 & -0.17 & 3.55 & -14.96 & 17.03 & 773 \\
\hline Cash only & 0.47 & 0.00 & 0.50 & 0.00 & 1.00 & 59 & 0.40 & 0.00 & 0.49 & 0.00 & 1.00 & 869 \\
\hline Stock only & 0.20 & 0.00 & 0.41 & 0.00 & 1.00 & 59 & 0.25 & 0.00 & 0.43 & 0.00 & 1.00 & 869 \\
\hline Hostile & 0.07 & 0.00 & 0.25 & 0.00 & 1.00 & 59 & 0.03 & 0.00 & 0.16 & 0.00 & 1.00 & 869 \\
\hline Tender & 0.19 & 0.00 & 0.39 & 0.00 & 1.00 & 59 & 0.19 & 0.00 & 0.39 & 0.00 & 1.00 & 869 \\
\hline
\end{tabular}


Table 2: Probit model of bid frequencies. The sample consists of 16,476 CEO-years from 1992 to 2008. The model estimates the probability of receiving a bid in a fiscal year (year $t$ ). The definition of a bid excludes share repurchases, privatizations, exchange offers, recapitalizations, and cases in which the acquirer owns $50 \%$ or more of target shares prior to the bid announcement. In the left panel, all bids satisfying these conditions are included. In the right panel, only bids in which the acquirer seeks to own more than 50\% of the target's shares are included. RET_AGE is a dummy variable equal to one if the target CEO is older than 65 in year t. CEO AGE and CEO AGE SQ. are age and age squared of the target CEO. AGE 61-65, AGE 51-55, and AGE < 51 are dummy variables equal to one if the target CEO age is in the specified range. TENURE is the number of years from the year the CEO takes office to year t. FOUNDER is a dummy variable set to one for CEOs who are in office at least five years before the firm's first year on Compustat. OWNERSHIP is the number of shares owned by the target CEO as a fraction of shares outstanding. B/M and MVEQ are the ratio of the book value to the market value of equity, and the market value of equity (\$ billions) of the target firm in year t-1. FIRM AGE is the number of years since the firm appears on Compustat. ROA is the average return on assets of the target firm in years t-3 through t-1. PAST RETURN is the average monthly industry-adjusted return from month -15 through -4 before year t. T-statistics are in parentheses. Prob. at 0 (1) is the implied probability of receiving a bid for target CEOs with RET_AGE $=0(1)$ and all other control variables at their means. 
Table 2, cont.: Probit model of bid frequencies.

\begin{tabular}{|c|c|c|c|c|c|c|c|c|c|c|c|c|}
\hline \multirow[b]{3}{*}{ Intercept } & \multicolumn{6}{|c|}{ All bids } & \multicolumn{6}{|c|}{ Bids for more than $50 \%$ of the target's shares } \\
\hline & \multicolumn{3}{|c|}{ Any bid } & \multicolumn{3}{|c|}{ Successful bid } & \multicolumn{3}{|c|}{ Any bid } & \multicolumn{3}{|c|}{ Successful bid } \\
\hline & $\begin{array}{c}-0.92 \\
(-7.43)\end{array}$ & $\begin{array}{c}-1.06 \\
(-13.48)\end{array}$ & $\begin{array}{c}-1.09 \\
(-2.11)\end{array}$ & $\begin{array}{c}-0.92 \\
(-6.90)\end{array}$ & $\begin{array}{c}-0.92 \\
(-10.86)\end{array}$ & $\begin{array}{c}-1.01 \\
(-1.81)\end{array}$ & $\begin{array}{c}-1.69 \\
(-11.65)\end{array}$ & $\begin{array}{c}-1.44 \\
(-15.84)\end{array}$ & $\begin{array}{c}-2.82 \\
(-4.30)\end{array}$ & $\begin{array}{c}-1.74 \\
(-10.55)\end{array}$ & $\begin{array}{c}-1.25 \\
(-12.16)\end{array}$ & $\begin{array}{c}-2.68 \\
(-3.59)\end{array}$ \\
\hline RET_AGE & $\begin{array}{c}0.23 \\
(3.90)\end{array}$ & $\begin{array}{c}0.21 \\
(3.68)\end{array}$ & $\begin{array}{c}0.25 \\
(3.32)\end{array}$ & $\begin{array}{c}0.20 \\
(3.12)\end{array}$ & $\begin{array}{c}0.19 \\
(3.12)\end{array}$ & $\begin{array}{c}0.21 \\
(2.58)\end{array}$ & $\begin{array}{c}0.13 \\
(1.92)\end{array}$ & $\begin{array}{c}0.18 \\
(2.79)\end{array}$ & $\begin{array}{c}0.23 \\
(2.62)\end{array}$ & $\begin{array}{c}0.13 \\
(1.74)\end{array}$ & $\begin{array}{c}0.21 \\
(2.88)\end{array}$ & $\begin{array}{c}0.21 \\
(2.18)\end{array}$ \\
\hline CEO age & $\begin{array}{c}0.00 \\
(-1.06)\end{array}$ & & $\begin{array}{c}0.00 \\
(0.23)\end{array}$ & $\begin{array}{c}0.00 \\
(-0.01)\end{array}$ & & $\begin{array}{c}0.00 \\
(0.16)\end{array}$ & $\begin{array}{c}0.00 \\
(1.77)\end{array}$ & & $\begin{array}{c}0.05 \\
(1.94)\end{array}$ & $\begin{array}{c}0.01 \\
(2.92)\end{array}$ & & $\begin{array}{c}0.04 \\
(1.59)\end{array}$ \\
\hline CEO age sq. & & & $\begin{array}{c}0.00 \\
(-0.35)\end{array}$ & & & $\begin{array}{c}0.00 \\
(-0.16)\end{array}$ & & & $\begin{array}{c}0.00 \\
(-1.79)\end{array}$ & & & $\begin{array}{c}0.00 \\
(-1.31)\end{array}$ \\
\hline Age 61-65 & & $\begin{array}{c}-0.01 \\
(-0.31)\end{array}$ & & & $\begin{array}{c}-0.04 \\
(-0.91)\end{array}$ & & & $\begin{array}{l}0.02 \\
(0.34)\end{array}$ & & & $\begin{array}{l}-0.02 \\
(-0.33)\end{array}$ & \\
\hline Age 51-55 & & $\begin{array}{c}0.01 \\
(0.15)\end{array}$ & & & $\begin{array}{c}0.00 \\
(0.07)\end{array}$ & & & $\begin{array}{l}-0.03 \\
(-0.67)\end{array}$ & & & $\begin{array}{l}-0.05 \\
(-1.09)\end{array}$ & \\
\hline Age $<51$ & & $\begin{array}{c}0.04 \\
(1.25)\end{array}$ & & & $\begin{array}{c}0.00 \\
(-0.07)\end{array}$ & & & $\begin{array}{l}-0.05 \\
(-1.25)\end{array}$ & & & $\begin{array}{l}-0.13 \\
(-2.75)\end{array}$ & \\
\hline Tenure & $\begin{array}{c}-0.01 \\
(-3.10)\end{array}$ & $\begin{array}{c}-0.01 \\
(-3.07)\end{array}$ & $\begin{array}{c}-0.01 \\
(-3.04)\end{array}$ & $\begin{array}{c}-0.01 \\
(-2.46)\end{array}$ & $\begin{array}{c}-0.01 \\
(-2.28)\end{array}$ & $\begin{array}{c}-0.01 \\
(-2.42)\end{array}$ & $\begin{array}{c}-0.01 \\
(-3.78)\end{array}$ & $\begin{array}{c}-0.01 \\
(-3.69)\end{array}$ & $\begin{array}{c}-0.01 \\
(-3.56)\end{array}$ & $\begin{array}{c}-0.01 \\
(-3.58)\end{array}$ & $\begin{array}{c}-0.01 \\
(-3.35)\end{array}$ & $\begin{array}{c}-0.01 \\
(-3.42)\end{array}$ \\
\hline Founder & $\begin{array}{c}-0.10 \\
(-1.59)\end{array}$ & $\begin{array}{c}-0.10 \\
(-1.60)\end{array}$ & $\begin{array}{c}-0.10 \\
(-1.59)\end{array}$ & $\begin{array}{c}-0.14 \\
(-2.20)\end{array}$ & $\begin{array}{c}-0.15 \\
(-2.25)\end{array}$ & $\begin{array}{c}-0.14 \\
(-2.20)\end{array}$ & $\begin{array}{c}-0.04 \\
(-0.58)\end{array}$ & $\begin{array}{c}-0.04 \\
(-0.59)\end{array}$ & $\begin{array}{c}-0.04 \\
(-0.61)\end{array}$ & $\begin{array}{c}-0.06 \\
(-0.74)\end{array}$ & $\begin{array}{c}-0.06 \\
(-0.78)\end{array}$ & $\begin{array}{c}-0.06 \\
(-0.76)\end{array}$ \\
\hline Ownership & $\begin{array}{c}0.16 \\
(0.75)\end{array}$ & $\begin{array}{c}0.16 \\
(0.74)\end{array}$ & $\begin{array}{c}0.16 \\
(0.78)\end{array}$ & $\begin{array}{c}0.06 \\
(0.25)\end{array}$ & $\begin{array}{c}0.06 \\
(0.25)\end{array}$ & $\begin{array}{c}0.06 \\
(0.26)\end{array}$ & $\begin{array}{c}-0.08 \\
(-0.30)\end{array}$ & $\begin{array}{c}-0.08 \\
(-0.32)\end{array}$ & $\begin{array}{c}-0.04 \\
(-0.16)\end{array}$ & $\begin{array}{c}-0.56 \\
(-1.67)\end{array}$ & $\begin{array}{c}-0.55 \\
(-1.66)\end{array}$ & $\begin{array}{c}-0.52 \\
(-1.56)\end{array}$ \\
\hline Past return & $\begin{array}{c}-2.75 \\
(-7.45)\end{array}$ & $\begin{array}{c}-2.75 \\
(-7.45)\end{array}$ & $\begin{array}{c}-2.75 \\
(-7.44)\end{array}$ & $\begin{array}{c}-2.47 \\
(-6.27)\end{array}$ & $\begin{array}{c}-2.47 \\
(-6.27)\end{array}$ & $\begin{array}{c}-2.47 \\
(-6.27)\end{array}$ & $\begin{array}{c}-2.77 \\
(-6.39)\end{array}$ & $\begin{array}{c}-2.77 \\
(-6.41)\end{array}$ & $\begin{array}{c}-2.77 \\
(-6.38)\end{array}$ & $\begin{array}{c}-2.39 \\
(-4.96)\end{array}$ & $\begin{array}{c}-2.40 \\
(-4.98)\end{array}$ & $\begin{array}{c}-2.39 \\
(-4.95)\end{array}$ \\
\hline $\mathrm{B} / \mathrm{M}$ & $\begin{array}{c}0.04 \\
(1.26)\end{array}$ & $\begin{array}{c}0.05 \\
(1.27)\end{array}$ & $\begin{array}{c}0.04 \\
(1.26)\end{array}$ & $\begin{array}{c}-0.04 \\
(-0.92)\end{array}$ & $\begin{array}{c}-0.04 \\
(-0.90)\end{array}$ & $\begin{array}{c}-0.04 \\
(-0.92)\end{array}$ & $\begin{array}{c}0.00 \\
(-0.06)\end{array}$ & $\begin{array}{c}0.00 \\
(-0.03)\end{array}$ & $\begin{array}{c}0.00 \\
(-0.06)\end{array}$ & $\begin{array}{c}-0.15 \\
(-2.99)\end{array}$ & $\begin{array}{c}-0.15 \\
(-2.96)\end{array}$ & $\begin{array}{c}-0.15 \\
(-2.99)\end{array}$ \\
\hline MVEQ & $\begin{array}{c}-0.02 \\
(-2.37)\end{array}$ & $\begin{array}{c}-0.02 \\
(-2.32)\end{array}$ & $\begin{array}{c}-0.02 \\
(-2.39)\end{array}$ & $\begin{array}{c}-0.05 \\
(-5.13)\end{array}$ & $\begin{array}{c}-0.05 \\
(-5.11)\end{array}$ & $\begin{array}{c}-0.05 \\
(-5.13)\end{array}$ & $\begin{array}{c}0.01 \\
(0.63)\end{array}$ & $\begin{array}{c}0.01 \\
(0.64)\end{array}$ & $\begin{array}{c}0.01 \\
(0.56)\end{array}$ & $\begin{array}{c}-0.03 \\
(-2.53)\end{array}$ & $\begin{array}{c}-0.03 \\
(-2.56)\end{array}$ & $\begin{array}{c}-0.03 \\
(-2.59)\end{array}$ \\
\hline ROA & $\begin{array}{c}-0.85 \\
(-7.88)\end{array}$ & $\begin{array}{c}-0.85 \\
(-7.87)\end{array}$ & $\begin{array}{c}-0.85 \\
(-7.87)\end{array}$ & $\begin{array}{c}-0.79 \\
(-6.85)\end{array}$ & $\begin{array}{c}-0.79 \\
(-6.85)\end{array}$ & $\begin{array}{c}-0.79 \\
(-6.84)\end{array}$ & $\begin{array}{c}-0.68 \\
(-5.33)\end{array}$ & $\begin{array}{c}-0.68 \\
(-5.34)\end{array}$ & $\begin{array}{c}-0.68 \\
(-5.32)\end{array}$ & $\begin{array}{c}-0.60 \\
(-4.21)\end{array}$ & $\begin{array}{c}-0.60 \\
(-4.23)\end{array}$ & $\begin{array}{c}-0.60 \\
(-4.20)\end{array}$ \\
\hline Firm age & $\begin{array}{c}-0.01 \\
(-5.58)\end{array}$ & $\begin{array}{c}-0.01 \\
(-5.55)\end{array}$ & $\begin{array}{c}-0.01 \\
(-5.57)\end{array}$ & $\begin{array}{c}-0.01 \\
(-5.18)\end{array}$ & $\begin{array}{c}-0.01 \\
(-5.13)\end{array}$ & $\begin{array}{c}-0.01 \\
(-5.17)\end{array}$ & $\begin{array}{c}-0.01 \\
(-4.94)\end{array}$ & $\begin{array}{c}-0.01 \\
(-4.88)\end{array}$ & $\begin{array}{c}-0.01 \\
(-4.93)\end{array}$ & $\begin{array}{c}0.00 \\
(-3.83)\end{array}$ & $\begin{array}{c}0.00 \\
(-3.75)\end{array}$ & $\begin{array}{c}0.00 \\
(-3.82)\end{array}$ \\
\hline $\mathrm{N}$ no event & 21,809 & 21,809 & 21,809 & 22,174 & 22,174 & 22,174 & 22,447 & 22,447 & 22,447 & 22,765 & 22,765 & 22,765 \\
\hline $\mathrm{N}$ event & 1,724 & 1,724 & 1,724 & 1,346 & 1,346 & 1,346 & 1,081 & 1,081 & 1,081 & 752 & 752 & 752 \\
\hline Prob. at 0 & 0.07 & 0.07 & 0.07 & 0.05 & 0.05 & 0.05 & 0.04 & 0.04 & 0.04 & 0.03 & 0.03 & 0.03 \\
\hline Prob. at 1 & 0.10 & 0.10 & 0.11 & 0.08 & 0.08 & 0.08 & 0.06 & 0.06 & 0.07 & 0.04 & 0.05 & 0.05 \\
\hline
\end{tabular}


Table 3: Takeover premium and target announcement return regressions. The dependent variable in the first six columns is the target's cumulative industry-adjusted daily stock return from day -t before to day +1 after the announcement of the first control bid in the contest. In the last three columns, the dependent variable is the takeover premium measured from trading day -20 before the first announcement to the final offer price, adjusted for the cumulative industry return over the same period. RET_AGE is a dummy variable equal to one if the target CEO is older than 65 in the announcement year. All target CEO and firm characteristics are as described in Table 1. T-statistics are in parentheses.

\begin{tabular}{|c|c|c|c|c|c|c|c|c|c|}
\hline \multirow[b]{2}{*}{ Intercept } & \multicolumn{3}{|c|}{ Return $(-3,1)$} & \multicolumn{3}{|c|}{ Return(-20, 1) } & \multicolumn{3}{|c|}{ Premium(-20, final) } \\
\hline & $\begin{array}{c}0.29 \\
(3.87)\end{array}$ & $\begin{array}{c}0.31 \\
(6.10)\end{array}$ & $\begin{array}{c}0.25 \\
(0.76)\end{array}$ & $\begin{array}{c}0.29 \\
(3.61)\end{array}$ & $\begin{array}{c}0.35 \\
(6.29)\end{array}$ & $\begin{array}{c}0.00 \\
(-0.01)\end{array}$ & $\begin{array}{c}0.51 \\
(5.16)\end{array}$ & $\begin{array}{c}0.50 \\
(7.21)\end{array}$ & $\begin{array}{c}0.43 \\
(0.99)\end{array}$ \\
\hline RET_AGE & $\begin{array}{c}-0.08 \\
(-2.54)\end{array}$ & $\begin{array}{l}-0.07 \\
(-2.41)\end{array}$ & $\begin{array}{c}-0.08 \\
(-1.88)\end{array}$ & $\begin{array}{c}-0.10 \\
(-2.87)\end{array}$ & $\begin{array}{c}-0.08 \\
(-2.52)\end{array}$ & $\begin{array}{c}-0.08 \\
(-1.67)\end{array}$ & $\begin{array}{c}-0.10 \\
(-2.48)\end{array}$ & $\begin{array}{c}-0.11 \\
(-2.66)\end{array}$ & $\begin{array}{c}-0.10 \\
(-1.78)\end{array}$ \\
\hline CEO age & $\begin{array}{c}0.00 \\
(0.49)\end{array}$ & & $\begin{array}{c}0.00 \\
(0.16)\end{array}$ & $\begin{array}{c}0.00 \\
(0.90)\end{array}$ & & $\begin{array}{c}0.01 \\
(0.93)\end{array}$ & $\begin{array}{c}0.00 \\
(-0.11)\end{array}$ & & $\begin{array}{c}0.00 \\
(0.18)\end{array}$ \\
\hline CEO age sq. & & & $\begin{array}{c}0.00 \\
(-0.11)\end{array}$ & & & $\begin{array}{c}0.00 \\
(-0.85)\end{array}$ & & & $\begin{array}{c}0.00 \\
(-0.20)\end{array}$ \\
\hline Age 61-65 & & $\begin{array}{c}0.00 \\
(0.09)\end{array}$ & & & $\begin{array}{c}0.02 \\
(0.63)\end{array}$ & & & $\begin{array}{c}0.01 \\
(0.49)\end{array}$ & \\
\hline Age 51-55 & & $\begin{array}{c}0.00 \\
(0.13)\end{array}$ & & & $\begin{array}{c}0.00 \\
(-0.11)\end{array}$ & & & $\begin{array}{c}-0.01 \\
(-0.55)\end{array}$ & \\
\hline Age $<51$ & & $\begin{array}{c}0.00 \\
(-0.05)\end{array}$ & & & $\begin{array}{c}-0.01 \\
(-0.30)\end{array}$ & & & $\begin{array}{c}0.01 \\
(0.37)\end{array}$ & \\
\hline Tenure & $\begin{array}{c}0.00 \\
(1.82)\end{array}$ & $\begin{array}{c}0.00 \\
(1.90)\end{array}$ & $\begin{array}{c}0.00 \\
(1.82)\end{array}$ & $\begin{array}{c}0.00 \\
(1.72)\end{array}$ & $\begin{array}{c}0.00 \\
(1.74)\end{array}$ & $\begin{array}{c}0.00 \\
(1.76)\end{array}$ & $\begin{array}{c}0.01 \\
(2.76)\end{array}$ & $\begin{array}{c}0.01 \\
(2.71)\end{array}$ & $\begin{array}{c}0.01 \\
(2.76)\end{array}$ \\
\hline Founder & $\begin{array}{c}-0.01 \\
(-0.34)\end{array}$ & $\begin{array}{c}-0.01 \\
(-0.37)\end{array}$ & $\begin{array}{c}-0.01 \\
(-0.34)\end{array}$ & $\begin{array}{c}-0.02 \\
(-0.35)\end{array}$ & $\begin{array}{c}-0.01 \\
(-0.32)\end{array}$ & $\begin{array}{c}-0.02 \\
(-0.39)\end{array}$ & $\begin{array}{c}-0.04 \\
(-0.78)\end{array}$ & $\begin{array}{c}-0.04 \\
(-0.70)\end{array}$ & $\begin{array}{c}-0.04 \\
(-0.79)\end{array}$ \\
\hline Ownership & $\begin{array}{c}-0.36 \\
(-2.05)\end{array}$ & $\begin{array}{c}-0.36 \\
(-2.04)\end{array}$ & $\begin{array}{c}-0.35 \\
(-2.01)\end{array}$ & $\begin{array}{c}-0.25 \\
(-1.31)\end{array}$ & $\begin{array}{c}-0.25 \\
(-1.31)\end{array}$ & $\begin{array}{c}-0.22 \\
(-1.17)\end{array}$ & $\begin{array}{c}-0.46 \\
(-2.05)\end{array}$ & $\begin{array}{c}-0.48 \\
(-2.10)\end{array}$ & $\begin{array}{c}-0.46 \\
(-2.00)\end{array}$ \\
\hline $\mathrm{B} / \mathrm{M}$ & $\begin{array}{c}-0.01 \\
(-0.67)\end{array}$ & $\begin{array}{c}-0.01 \\
(-0.62)\end{array}$ & $\begin{array}{c}-0.01 \\
(-0.67)\end{array}$ & $\begin{array}{c}-0.03 \\
(-1.31)\end{array}$ & $\begin{array}{c}-0.03 \\
(-1.27)\end{array}$ & $\begin{array}{c}-0.03 \\
(-1.36)\end{array}$ & $\begin{array}{c}0.00 \\
(-0.11)\end{array}$ & $\begin{array}{c}0.00 \\
(-0.13)\end{array}$ & $\begin{array}{c}0.00 \\
(-0.12)\end{array}$ \\
\hline MVEQ & $\begin{array}{c}-0.02 \\
(-3.71)\end{array}$ & $\begin{array}{c}-0.02 \\
(-3.64)\end{array}$ & $\begin{array}{c}-0.02 \\
(-3.71)\end{array}$ & $\begin{array}{c}-0.02 \\
(-3.51)\end{array}$ & $\begin{array}{c}-0.02 \\
(-3.46)\end{array}$ & $\begin{array}{c}-0.02 \\
(-3.52)\end{array}$ & $\begin{array}{c}-0.02 \\
(-3.27)\end{array}$ & $\begin{array}{c}-0.03 \\
(-3.29)\end{array}$ & $\begin{array}{c}-0.02 \\
(-3.27)\end{array}$ \\
\hline ROA & $\begin{array}{c}-0.07 \\
(-0.83)\end{array}$ & $\begin{array}{l}-0.07 \\
(-0.81)\end{array}$ & $\begin{array}{c}-0.07 \\
(-0.83)\end{array}$ & $\begin{array}{c}-0.14 \\
(-1.60)\end{array}$ & $\begin{array}{c}-0.14 \\
(-1.58)\end{array}$ & $\begin{array}{c}-0.15 \\
(-1.68)\end{array}$ & $\begin{array}{c}-0.25 \\
(-2.30)\end{array}$ & $\begin{array}{c}-0.24 \\
(-2.27)\end{array}$ & $\begin{array}{c}-0.25 \\
(-2.31)\end{array}$ \\
\hline Past return & $\begin{array}{c}-0.49 \\
(-2.39)\end{array}$ & $\begin{array}{c}-0.49 \\
(-2.36)\end{array}$ & $\begin{array}{c}-0.49 \\
(-2.38)\end{array}$ & $\begin{array}{c}-0.60 \\
(-2.69)\end{array}$ & $\begin{array}{c}-0.60 \\
(-2.69)\end{array}$ & $\begin{array}{c}-0.60 \\
(-2.67)\end{array}$ & $\begin{array}{c}-0.56 \\
(-2.02)\end{array}$ & $\begin{array}{c}-0.56 \\
(-2.02)\end{array}$ & $\begin{array}{c}-0.56 \\
(-2.01)\end{array}$ \\
\hline Cash only & $\begin{array}{c}0.05 \\
(2.92)\end{array}$ & $\begin{array}{c}0.05 \\
(2.91)\end{array}$ & $\begin{array}{c}0.05 \\
(2.92)\end{array}$ & $\begin{array}{c}0.06 \\
(3.25)\end{array}$ & $\begin{array}{c}0.06 \\
(3.23)\end{array}$ & $\begin{array}{c}0.06 \\
(3.26)\end{array}$ & $\begin{array}{c}0.01 \\
(0.24)\end{array}$ & $\begin{array}{c}0.00 \\
(0.21)\end{array}$ & $\begin{array}{c}0.01 \\
(0.24)\end{array}$ \\
\hline Stock only & $\begin{array}{c}-0.02 \\
(-1.09)\end{array}$ & $\begin{array}{c}-0.02 \\
(-1.09)\end{array}$ & $\begin{array}{c}-0.02 \\
(-1.09)\end{array}$ & $\begin{array}{c}-0.02 \\
(-0.76)\end{array}$ & $\begin{array}{c}-0.02 \\
(-0.75)\end{array}$ & $\begin{array}{c}-0.02 \\
(-0.79)\end{array}$ & $\begin{array}{c}-0.02 \\
(-0.63)\end{array}$ & $\begin{array}{c}-0.01 \\
(-0.58)\end{array}$ & $\begin{array}{c}-0.02 \\
(-0.64)\end{array}$ \\
\hline Hostile & $\begin{array}{c}0.04 \\
(1.07)\end{array}$ & $\begin{array}{c}0.04 \\
(1.09)\end{array}$ & $\begin{array}{c}0.04 \\
(1.07)\end{array}$ & $\begin{array}{c}0.01 \\
(0.16)\end{array}$ & $\begin{array}{c}0.01 \\
(0.20)\end{array}$ & $\begin{array}{c}0.01 \\
(0.15)\end{array}$ & $\begin{array}{c}0.14 \\
(2.84)\end{array}$ & $\begin{array}{c}0.15 \\
(2.87)\end{array}$ & $\begin{array}{c}0.14 \\
(2.84)\end{array}$ \\
\hline Tender & $\begin{array}{c}0.09 \\
(4.76)\end{array}$ & $\begin{array}{c}0.09 \\
(4.74)\end{array}$ & $\begin{array}{c}0.09 \\
(4.76)\end{array}$ & $\begin{array}{c}0.10 \\
(4.85)\end{array}$ & $\begin{array}{c}0.10 \\
(4.83)\end{array}$ & $\begin{array}{c}0.10 \\
(4.86)\end{array}$ & $\begin{array}{c}0.10 \\
(4.07)\end{array}$ & $\begin{array}{c}0.10 \\
(4.08)\end{array}$ & $\begin{array}{c}0.10 \\
(4.07)\end{array}$ \\
\hline $\begin{array}{l}\text { Adj. R2 } \\
\mathrm{N}\end{array}$ & $\begin{array}{l}0.13 \\
724\end{array}$ & $\begin{array}{l}0.13 \\
724\end{array}$ & $\begin{array}{l}0.13 \\
724\end{array}$ & $\begin{array}{l}0.13 \\
724\end{array}$ & $\begin{array}{l}0.13 \\
724\end{array}$ & $\begin{array}{l}0.13 \\
724\end{array}$ & $\begin{array}{l}0.11 \\
703\end{array}$ & $\begin{array}{l}0.11 \\
703\end{array}$ & $\begin{array}{l}0.11 \\
703\end{array}$ \\
\hline
\end{tabular}


Table 4: Acquirer announcement return regressions. The dependent variable is the acquirer's cumulative industry-adjusted daily stock return from day -3 (or day -20) before to day +1 after the announcement of the first control bid in the contest. RET_AGE is a dummy variable equal to one if the target CEO is older than 65 in the announcement year. All target CEO and target firm characteristics are as described in Table 1. RELATIVE SIZE is the ratio of the target's equity market value to the combined market value of the target and the acquirer in the year prior to the announcement. T-statistics are in parentheses.

\begin{tabular}{|c|c|c|c|c|c|c|}
\hline \multirow[b]{2}{*}{ Intercept } & \multicolumn{3}{|c|}{ Return $(-3,1)$} & \multicolumn{3}{|c|}{ Return $(-20,1)$} \\
\hline & $\begin{array}{c}-0.04 \\
(-1.14)\end{array}$ & $\begin{array}{c}0.00 \\
(0.17)\end{array}$ & $\begin{array}{c}-0.17 \\
(-0.94)\end{array}$ & $\begin{array}{c}0.04 \\
(0.63)\end{array}$ & $\begin{array}{c}0.07 \\
(1.81)\end{array}$ & $\begin{array}{c}-0.31 \\
(-1.22)\end{array}$ \\
\hline RET_AGE & $\begin{array}{c}0.01 \\
(0.33)\end{array}$ & $\begin{array}{c}0.01 \\
(0.71)\end{array}$ & $\begin{array}{c}0.02 \\
(0.70)\end{array}$ & $\begin{array}{c}0.02 \\
(0.65)\end{array}$ & $\begin{array}{c}0.00 \\
(0.17)\end{array}$ & $\begin{array}{c}0.04 \\
(1.37)\end{array}$ \\
\hline CEO age & $\begin{array}{c}0.00 \\
(1.31)\end{array}$ & & $\begin{array}{c}0.01 \\
(0.83)\end{array}$ & $\begin{array}{c}0.00 \\
(0.31)\end{array}$ & & $\begin{array}{c}0.01 \\
(1.41)\end{array}$ \\
\hline CEO age sq. & & & $\begin{array}{c}0.00 \\
(-0.71)\end{array}$ & & & $\begin{array}{c}0.00 \\
(-1.39)\end{array}$ \\
\hline Age 61-65 & & $\begin{array}{c}0.00 \\
(0.03)\end{array}$ & & & $\begin{array}{c}-0.03 \\
(-1.89)\end{array}$ & \\
\hline Age 51-55 & & $\begin{array}{c}-0.01 \\
(-1.07)\end{array}$ & & & $\begin{array}{c}-0.02 \\
(-1.57)\end{array}$ & \\
\hline Age $<51$ & & $\begin{array}{c}-0.01 \\
(-0.93)\end{array}$ & & & $\begin{array}{c}-0.02 \\
(-1.12)\end{array}$ & \\
\hline Tenure & $\begin{array}{c}0.00 \\
(-1.65)\end{array}$ & $\begin{array}{c}0.00 \\
(-1.55)\end{array}$ & $\begin{array}{c}0.00 \\
(-1.67)\end{array}$ & $\begin{array}{c}0.00 \\
(-1.31)\end{array}$ & $\begin{array}{c}0.00 \\
(-1.07)\end{array}$ & $\begin{array}{c}0.00 \\
(-1.34)\end{array}$ \\
\hline Founder & $\begin{array}{c}0.00 \\
(0.20)\end{array}$ & $\begin{array}{c}0.00 \\
(0.11)\end{array}$ & $\begin{array}{c}0.00 \\
(0.25)\end{array}$ & $\begin{array}{c}0.00 \\
(-0.06)\end{array}$ & $\begin{array}{c}0.00 \\
(-0.22)\end{array}$ & $\begin{array}{c}0.00 \\
(0.04)\end{array}$ \\
\hline Ownership & $\begin{array}{c}0.01 \\
(0.13)\end{array}$ & $\begin{array}{c}0.01 \\
(0.14)\end{array}$ & $\begin{array}{c}0.02 \\
(0.16)\end{array}$ & $\begin{array}{c}-0.13 \\
(-0.99)\end{array}$ & $\begin{array}{c}-0.14 \\
(-1.04)\end{array}$ & $\begin{array}{c}-0.13 \\
(-0.92)\end{array}$ \\
\hline $\mathrm{B} / \mathrm{M}$ & $\begin{array}{c}0.02 \\
(1.35)\end{array}$ & $\begin{array}{c}0.02 \\
(1.36)\end{array}$ & $\begin{array}{c}0.02 \\
(1.34)\end{array}$ & $\begin{array}{c}0.01 \\
(0.44)\end{array}$ & $\begin{array}{c}0.01 \\
(0.42)\end{array}$ & $\begin{array}{c}0.01 \\
(0.43)\end{array}$ \\
\hline MVEQ & $\begin{array}{c}0.00 \\
(-1.39)\end{array}$ & $\begin{array}{c}0.00 \\
(-1.43)\end{array}$ & $\begin{array}{c}0.00 \\
(-1.41)\end{array}$ & $\begin{array}{c}-0.01 \\
(-1.97)\end{array}$ & $\begin{array}{c}-0.01 \\
(-2.15)\end{array}$ & $\begin{array}{c}-0.01 \\
(-2.02)\end{array}$ \\
\hline ROA & $\begin{array}{c}-0.01 \\
(-0.30)\end{array}$ & $\begin{array}{c}-0.01 \\
(-0.24)\end{array}$ & $\begin{array}{c}-0.01 \\
(-0.31)\end{array}$ & $\begin{array}{c}0.02 \\
(0.44)\end{array}$ & $\begin{array}{c}0.03 \\
(0.63)\end{array}$ & $\begin{array}{c}0.02 \\
(0.42)\end{array}$ \\
\hline Past return & $\begin{array}{c}0.07 \\
(0.60)\end{array}$ & $\begin{array}{c}0.07 \\
(0.62)\end{array}$ & $\begin{array}{c}0.07 \\
(0.63)\end{array}$ & $\begin{array}{c}0.14 \\
(0.86)\end{array}$ & $\begin{array}{c}0.17 \\
(1.02)\end{array}$ & $\begin{array}{c}0.15 \\
(0.90)\end{array}$ \\
\hline Cash only & $\begin{array}{c}0.02 \\
(1.83)\end{array}$ & $\begin{array}{c}0.02 \\
(1.81)\end{array}$ & $\begin{array}{c}0.02 \\
(1.81)\end{array}$ & $\begin{array}{c}0.00 \\
(-0.29)\end{array}$ & $\begin{array}{c}0.00 \\
(-0.24)\end{array}$ & $\begin{array}{c}0.00 \\
(-0.33)\end{array}$ \\
\hline Stock only & $\begin{array}{c}0.00 \\
(0.39)\end{array}$ & $\begin{array}{c}0.00 \\
(0.33)\end{array}$ & $\begin{array}{c}0.00 \\
(0.36)\end{array}$ & $\begin{array}{c}0.00 \\
(-0.19)\end{array}$ & $\begin{array}{c}0.00 \\
(-0.34)\end{array}$ & $\begin{array}{c}0.00 \\
(-0.25)\end{array}$ \\
\hline Hostile & $\begin{array}{c}0.02 \\
(0.99)\end{array}$ & $\begin{array}{c}0.02 \\
(1.01)\end{array}$ & $\begin{array}{c}0.02 \\
(0.97)\end{array}$ & $\begin{array}{c}0.04 \\
(1.49)\end{array}$ & $\begin{array}{c}0.04 \\
(1.46)\end{array}$ & $\begin{array}{c}0.04 \\
(1.44)\end{array}$ \\
\hline Tender & $\begin{array}{c}-0.01 \\
(-0.91)\end{array}$ & $\begin{array}{c}-0.01 \\
(-0.96)\end{array}$ & $\begin{array}{c}-0.01 \\
(-0.91)\end{array}$ & $\begin{array}{c}-0.02 \\
(-1.47)\end{array}$ & $\begin{array}{c}-0.02 \\
(-1.54)\end{array}$ & $\begin{array}{c}-0.02 \\
(-1.46)\end{array}$ \\
\hline Relative size & $\begin{array}{c}-0.05 \\
(-2.07)\end{array}$ & $\begin{array}{c}-0.05 \\
(-2.06)\end{array}$ & $\begin{array}{c}-0.05 \\
(-2.09)\end{array}$ & $\begin{array}{c}-0.04 \\
(-1.22)\end{array}$ & $\begin{array}{c}-0.04 \\
(-1.23)\end{array}$ & $\begin{array}{c}-0.04 \\
(-1.26)\end{array}$ \\
\hline $\mathrm{B} / \mathrm{M}$ acquirer & $\begin{array}{c}0.00 \\
(0.18)\end{array}$ & $\begin{array}{c}0.00 \\
(0.12)\end{array}$ & $\begin{array}{c}0.00 \\
(0.17)\end{array}$ & $\begin{array}{c}0.02 \\
(0.94)\end{array}$ & $\begin{array}{c}0.02 \\
(0.93)\end{array}$ & $\begin{array}{c}0.02 \\
(0.93)\end{array}$ \\
\hline $\begin{array}{l}\text { Adj. R2 } \\
\mathrm{N}\end{array}$ & $\begin{array}{r}0.03 \\
469\end{array}$ & $\begin{array}{c}0.03 \\
469\end{array}$ & $\begin{array}{c}0.03 \\
469\end{array}$ & $\begin{array}{c}0.01 \\
469\end{array}$ & $\begin{array}{c}0.01 \\
469\end{array}$ & $\begin{array}{c}0.01 \\
469\end{array}$ \\
\hline
\end{tabular}


Table 5: Stock return performance prior to the bid. The table shows regressions of target stock returns before a takeover bid (in percent) on the retirement-age indicator (RET_AGE) and other CEO and firm characteristics. The dependent variable is the target's average monthly industry-adjusted stock return estimated over one year, three years, or all CEO tenure years, and ending three months before the first bid announcement. The table shows only coefficients for the CEO age variables. The untabulated control variables are the target's book-to-market ratio, market value of equity, firm age, and CEO tenure and share ownership. T-statistics are in parentheses.

\begin{tabular}{lcccccc}
\hline & \multicolumn{2}{c}{ 1-year return } & \multicolumn{2}{c}{ 3-year return } & \multicolumn{2}{c}{ Tenure return } \\
\hline RET_AGE & 0.29 & 0.04 & 0.13 & -0.12 & 0.33 & 0.17 \\
& $(0.95)$ & $(0.13)$ & $(0.50)$ & $(-0.46)$ & $(1.09)$ & $(0.59)$ \\
CEO age & -0.03 & & -0.03 & & -0.02 & \\
& $(-2.50)$ & & $(-2.93)$ & & $(-2.13)$ & \\
Age 61-65 & & -0.13 & & -0.06 & & 0.00 \\
& & $(-0.59)$ & & $-0.30)$ & & $0.02)$ \\
Age 51-55 & & 0.36 & & 0.33 & & 0.37 \\
& & $(1.97)$ & & $(2.04)$ & & 0.37 \\
Age $<$ 51 & & 0.39 & 0.42 & & $(2.07)$ \\
& & $(2.15)$ & & $(2.60)$ & & \\
\hline
\end{tabular}


Table 6: Cross-sectional differences in the retirement-age effect on bid frequencies. The probit regressions in the table estimate the probability of receiving a takeover bid in a given year (year $t$ ) and are similar to those in column 2 of Table 2. In each column, the retirement-age indicator (RET_AGE) is interacted with a different CEO, firm, or industry characteristic described in the column's heading (and labeled CROSS in the table). PAST RETURN is the average monthly industry-adjusted stock return for months -15 to -4 before year t. INDUSTRY PAY is the average excess CEO pay for the target firm's industry, estimated as the loadings on industry dummies from a CEO pay regression. CEO PAY is the target CEO's average excess pay over the previous three years. Excess pay is estimated as the residual from the same CEO pay regression. FOUNDER is a dummy variable equal to one if the target CEO is in office five years before the firm appears on Compustat. HOLDINGS is the natural logarithm of the dollar value of the target CEO's stock and option holdings. ILLIQUID is the dollar value of the target CEO's stock and option holdings scaled by the CEO's total prior compensation. Total prior compensation is the CEO's median annual compensation during her tenure multiplied by the number of years in office (the median is based on years available on ExecuComp only). The dollar value of option holdings is approximated using intrinsic values. OWNERSHIP is the number of shares owned by the target CEO as a fraction of shares outstanding. All other control variables are as in Table 2 and are omitted from the table. T-statistics are in parentheses. T-statistics for the marginal interaction effect estimated at the mean of all control variables are in italics (Ai and Norton, 2003).

\begin{tabular}{lcccccccc}
\hline Cross variable: & $\begin{array}{c}\text { Past return } \\
\text { (1 year) }\end{array}$ & $\begin{array}{c}\text { Industry } \\
\text { pay }\end{array}$ & $\begin{array}{c}\text { CEO } \\
\text { pay }\end{array}$ & $\begin{array}{c}\text { CEO } \\
\text { performance }\end{array}$ & Founder & Holdings & Illiquid & Ownership \\
\hline RET_AGE & 0.207 & 0.204 & 0.212 & 0.233 & 0.224 & 0.206 & 0.205 & 0.176 \\
& $(3.646)$ & $(3.526)$ & $(3.562)$ & $(4.100)$ & $(3.699)$ & $(3.525)$ & $(3.488)$ & $(2.937)$ \\
Cross & -2.749 & 0.048 & 0.016 & -1.704 & -0.079 & -0.007 & -0.010 & -0.001 \\
& $(-7.246)$ & $(1.675)$ & $(3.070)$ & $(-3.650)$ & $(-1.241)$ & $(-0.820)$ & $(-2.267)$ & $(-0.004)$ \\
Cross* & & & & & & & & \\
RET_AGE & -0.082 & 0.115 & -0.014 & -0.851 & -0.090 & -0.002 & 0.001 & 0.864 \\
& $(-0.054)$ & $(1.143)$ & $(-0.724)$ & $(-0.340)$ & $(-0.742)$ & $(-0.112)$ & $(0.160)$ & $(1.697)$ \\
& $(-0.568)$ & $(1.366)$ & $(-0.453)$ & $(-0.472)$ & $(-0.955)$ & $(-0.266)$ & $(-0.182)$ & $(1.747)$ \\
\hline
\end{tabular}


Table 7: Descriptive statistics for the partial acquisitions sample. The sample consists of 1,184 partial acquisition bids from 1992 to 2008 , defined as bids through which the acquirer seeks to own less than 50\% of the target's shares. Cases in which the acquirer already owns $50 \%$ or more of the target's shares before the bid are excluded. SHARES OWNED PRE ANN., SHARED SOUGHT TO OWN, and SHARES ACQUIRED by the bidder are measured in percent of target shares outstanding. COMPLETED is an indicator variable for completed transactions. BLOCK (OPEN MARKET) are indicator variables for partial acquisitions classified as block purchases (open market purchases) by SDC. PREMIUM is defined as (final offer price - closing price on day zero) / (closing price on day zero) after the first bid. All other variables are defined as in Table 1.

\begin{tabular}{|c|c|c|c|c|c|c|c|c|c|c|c|c|}
\hline & \multicolumn{6}{|c|}{ Target CEOs above the retirement-age threshold } & \multicolumn{6}{|c|}{ Other target CEOs } \\
\hline & Mean & Median & Std & Min & Max & $\mathrm{N}$ & Mean & Median & Std & Min & Max & $\mathrm{N}$ \\
\hline \multicolumn{13}{|c|}{ Panel A: All partial acquisition bids } \\
\hline Shares owned pre ann. & 4.99 & 0.60 & 8.16 & 0.00 & 41.20 & 88 & 3.22 & 0.00 & 6.15 & 0.00 & 47.50 & 1,096 \\
\hline Shares sought to own & 11.59 & 8.75 & 9.08 & 0.50 & 48.00 & 88 & 10.98 & 7.90 & 9.23 & 0.00 & 49.90 & 1,096 \\
\hline Shares acquired & 5.56 & 4.87 & 5.11 & 0.08 & 26.05 & 74 & 7.31 & 5.10 & 8.04 & 0.01 & 49.90 & 936 \\
\hline Completed & 0.84 & 1.00 & 0.37 & 0.00 & 1.00 & 88 & 0.86 & 1.00 & 0.35 & 0.00 & 1.00 & 1,096 \\
\hline Block & 0.28 & 0.00 & 0.45 & 0.00 & 1.00 & 88 & 0.41 & 0.00 & 0.49 & 0.00 & 1.00 & 1,096 \\
\hline Open market & 0.64 & 1.00 & 0.48 & 0.00 & 1.00 & 88 & 0.53 & 1.00 & 0.50 & 0.00 & 1.00 & 1,096 \\
\hline Return (-3 to 1 ) & 0.04 & 0.02 & 0.10 & -0.25 & 0.47 & 85 & 0.04 & 0.02 & 0.13 & -0.83 & 0.97 & 1,063 \\
\hline CEO age & 70.06 & 69.00 & 4.03 & 66.00 & 82.00 & 88 & 51.71 & 52.00 & 6.90 & 29.00 & 65.00 & 1,096 \\
\hline $\mathrm{B} / \mathrm{M}$ & 0.75 & 0.63 & 0.56 & 0.04 & 3.40 & 81 & 0.65 & 0.55 & 0.50 & 0.04 & 3.40 & 1,035 \\
\hline MVEQ & 2,584 & 588 & 5,099 & 33 & 24,841 & 85 & 3,126 & 480 & 11,984 & 3 & 147,040 & 1,055 \\
\hline Firm age & 24.89 & 26.00 & 14.89 & 0.00 & 56.00 & 85 & 17.65 & 11.00 & 15.26 & 0.00 & 57.00 & 1,055 \\
\hline ROA & 0.03 & 0.03 & 0.08 & -0.34 & 0.19 & 82 & 0.00 & 0.02 & 0.15 & -0.72 & 0.34 & 998 \\
\hline \multicolumn{13}{|c|}{ Panel B: Partial acquisition bids classified as "block purchases" by SDC } \\
\hline Shares owned pre ann. & 3.71 & 0.00 & 9.56 & 0.00 & 41.20 & 25 & 2.08 & 0.00 & 5.76 & 0.00 & 40.90 & 449 \\
\hline Shares sought to own & 14.93 & 14.20 & 11.88 & 1.40 & 48.00 & 25 & 12.75 & 9.90 & 9.83 & 0.30 & 49.90 & 449 \\
\hline Shares acquired & 10.42 & 8.82 & 6.59 & 1.01 & 26.05 & 17 & 10.96 & 8.24 & 8.94 & 0.01 & 49.90 & 333 \\
\hline Completed & 0.68 & 1.00 & 0.48 & 0.00 & 1.00 & 25 & 0.76 & 1.00 & 0.43 & 0.00 & 1.00 & 449 \\
\hline Return (-3 to 1) & 0.05 & 0.04 & 0.11 & -0.14 & 0.38 & 25 & 0.06 & 0.04 & 0.14 & -0.36 & 0.69 & 435 \\
\hline Premium (0 to final) & 0.27 & 0.14 & 0.39 & -0.07 & 1.15 & 9 & 0.09 & 0.02 & 0.25 & -0.32 & 1.15 & 196 \\
\hline CEO age & 70.28 & 69.00 & 3.65 & 66.00 & 82.00 & 25 & 51.13 & 51.00 & 6.75 & 29.00 & 65.00 & 449 \\
\hline $\mathrm{B} / \mathrm{M}$ & 0.74 & 0.66 & 0.36 & 0.08 & 1.42 & 25 & 0.62 & 0.52 & 0.50 & 0.04 & 3.40 & 423 \\
\hline MVEQ & 5,644 & 1,015 & 8,045 & 91 & 24,841 & 25 & 5,081 & 575 & 17,872 & 3 & 147,040 & 432 \\
\hline Firm age & 25.44 & 21.00 & 14.78 & 4.00 & 56.00 & 25 & 16.64 & 10.50 & 14.90 & 0.00 & 57.00 & 432 \\
\hline ROA & 0.03 & 0.03 & 0.04 & -0.06 & 0.14 & 25 & -0.03 & 0.01 & 0.17 & -0.72 & 0.34 & 405 \\
\hline
\end{tabular}


Table 8: Probit model of partial acquisition bid frequencies. The regressions estimate the probability of receiving a partial acquisition bid in a fiscal year. A partial acquisition bid is defined as a bid through which the acquirer seeks to own less than $50 \%$ of the target's shares. The classification of bids into BLOCK and OPEN MARKET is from SDC. The table shows regressions for different sub-samples of bids classified based on the fraction of target shares sought by the acquirer. Prob. at 0 (1) is the implied probability of receiving a bid for target CEOs with RET_AGE $=0$ (1) and all other control variables at their means. Other variables are defined as in Table 2. T-statistics are in parentheses.

\begin{tabular}{|c|c|c|c|c|c|c|c|c|}
\hline \multirow{3}{*}{$\begin{array}{l}\text { Bids to own: } \\
\text { Intercept }\end{array}$} & \multicolumn{6}{|c|}{ Block and open market (OM) transactions } & \multirow{3}{*}{$\begin{array}{c}\text { Block } \\
0-50 \% \\
-1.38 \\
(-6.59)\end{array}$} & \multirow{3}{*}{$\begin{array}{c}\mathrm{OM} \\
0-50 \% \\
-0.91 \\
(-4.48)\end{array}$} \\
\hline & & $0-50 \%$ of $\mathrm{s}$ & & $20-50 \%$ & $10-20 \%$ & $0-10 \%$ & & \\
\hline & $\begin{array}{c}-0.79 \\
(-5.01)\end{array}$ & $\begin{array}{c}-1.33 \\
(-13.12)\end{array}$ & $\begin{array}{c}-0.22 \\
(-0.36)\end{array}$ & $\begin{array}{c}-1.38 \\
(-4.24)\end{array}$ & $\begin{array}{c}-1.35 \\
(-5.12)\end{array}$ & $\begin{array}{c}-1.19 \\
(-6.63)\end{array}$ & & \\
\hline RET_AGE & $\begin{array}{c}0.34 \\
(4.47)\end{array}$ & $\begin{array}{c}0.22 \\
(3.05)\end{array}$ & $\begin{array}{c}0.29 \\
(3.01)\end{array}$ & $\begin{array}{c}0.37 \\
(2.27)\end{array}$ & $\begin{array}{c}0.37 \\
(2.82)\end{array}$ & $\begin{array}{c}0.22 \\
(2.52)\end{array}$ & $\begin{array}{c}0.29 \\
(2.61)\end{array}$ & $\begin{array}{c}0.25 \\
(2.65)\end{array}$ \\
\hline CEO age & $\begin{array}{c}-0.01 \\
(-3.48)\end{array}$ & & $\begin{array}{c}-0.03 \\
(-1.37)\end{array}$ & $\begin{array}{c}-0.01 \\
(-1.95)\end{array}$ & $\begin{array}{c}-0.01 \\
(-2.57)\end{array}$ & $\begin{array}{c}-0.01 \\
(-2.09)\end{array}$ & $\begin{array}{c}-0.01 \\
(-3.22)\end{array}$ & $\begin{array}{c}-0.01 \\
(-1.49)\end{array}$ \\
\hline CEO age sq. & & & $\begin{array}{c}0.00 \\
(0.96)\end{array}$ & & & & & \\
\hline Age 61-65 & & $\begin{array}{c}-0.09 \\
(-1.59)\end{array}$ & & & & & & \\
\hline Age 51-55 & & $\begin{array}{c}0.05 \\
(1.15)\end{array}$ & & & & & & \\
\hline Age $<51$ & & $\begin{array}{c}0.12 \\
(2.59)\end{array}$ & & & & & & \\
\hline Tenure & $\begin{array}{c}0.00 \\
(-0.59)\end{array}$ & $\begin{array}{c}0.00 \\
(-0.59)\end{array}$ & $\begin{array}{c}0.00 \\
(-0.68)\end{array}$ & $\begin{array}{c}-0.01 \\
(-0.83)\end{array}$ & $\begin{array}{c}0.00 \\
(-0.07)\end{array}$ & $\begin{array}{c}0.00 \\
(-0.54)\end{array}$ & $\begin{array}{c}0.00 \\
(-0.83)\end{array}$ & $\begin{array}{c}0.00 \\
(0.68)\end{array}$ \\
\hline Founder & $\begin{array}{c}-0.15 \\
(-1.94)\end{array}$ & $\begin{array}{c}-0.15 \\
(-1.95)\end{array}$ & $\begin{array}{c}-0.15 \\
(-1.93)\end{array}$ & $\begin{array}{c}-0.20 \\
(-1.13)\end{array}$ & $\begin{array}{c}-0.27 \\
(-1.82)\end{array}$ & $\begin{array}{c}-0.07 \\
(-0.88)\end{array}$ & $\begin{array}{c}-0.11 \\
(-1.01)\end{array}$ & $\begin{array}{c}-0.22 \\
(-2.31)\end{array}$ \\
\hline Ownership & $\begin{array}{c}0.33 \\
(1.27)\end{array}$ & $\begin{array}{c}0.34 \\
(1.31)\end{array}$ & $\begin{array}{c}0.30 \\
(1.16)\end{array}$ & $\begin{array}{c}0.58 \\
(1.22)\end{array}$ & $\begin{array}{c}0.73 \\
(1.88)\end{array}$ & $\begin{array}{c}0.15 \\
(0.51)\end{array}$ & $\begin{array}{c}-0.16 \\
(-0.36)\end{array}$ & $\begin{array}{c}0.49 \\
(1.68)\end{array}$ \\
\hline Past return & $\begin{array}{l}-2.23 \\
(-4.69)\end{array}$ & $\begin{array}{c}-2.23 \\
(-4.68)\end{array}$ & $\begin{array}{c}-2.25 \\
(-4.73)\end{array}$ & $\begin{array}{l}-3.76 \\
(-3.76)\end{array}$ & $\begin{array}{c}-2.61 \\
(-3.16)\end{array}$ & $\begin{array}{c}-0.94 \\
(-1.77)\end{array}$ & $\begin{array}{l}-2.87 \\
(-4.44)\end{array}$ & $\begin{array}{l}-1.44 \\
(-2.41)\end{array}$ \\
\hline $\mathrm{B} / \mathrm{M}$ & $\begin{array}{c}0.09 \\
(2.09)\end{array}$ & $\begin{array}{c}0.09 \\
(2.05)\end{array}$ & $\begin{array}{c}0.09 \\
(2.07)\end{array}$ & $\begin{array}{c}0.02 \\
(0.18)\end{array}$ & $\begin{array}{c}0.04 \\
(0.57)\end{array}$ & $\begin{array}{c}0.12 \\
(2.34)\end{array}$ & $\begin{array}{c}0.05 \\
(0.77)\end{array}$ & $\begin{array}{c}0.06 \\
(1.09)\end{array}$ \\
\hline MVEQ & $\begin{array}{c}-0.06 \\
(-4.49)\end{array}$ & $\begin{array}{c}-0.06 \\
(-4.51)\end{array}$ & $\begin{array}{c}-0.05 \\
(-4.46)\end{array}$ & $\begin{array}{c}-0.06 \\
(-2.34)\end{array}$ & $\begin{array}{c}-0.04 \\
(-1.82)\end{array}$ & $\begin{array}{c}-0.05 \\
(-3.52)\end{array}$ & $\begin{array}{c}0.02 \\
(1.53)\end{array}$ & $\begin{array}{c}-0.14 \\
(-8.40)\end{array}$ \\
\hline ROA & $\begin{array}{c}-0.84 \\
(-6.09)\end{array}$ & $\begin{array}{c}-0.84 \\
(-6.09)\end{array}$ & $\begin{array}{c}-0.85 \\
(-6.11)\end{array}$ & $\begin{array}{c}-0.82 \\
(-2.86)\end{array}$ & $\begin{array}{c}-1.08 \\
(-4.52)\end{array}$ & $\begin{array}{c}-0.67 \\
(-4.29)\end{array}$ & $\begin{array}{c}-1.60 \\
(-8.66)\end{array}$ & $\begin{array}{c}-0.14 \\
(-0.78)\end{array}$ \\
\hline Firm age & $\begin{array}{c}0.00 \\
(-3.34)\end{array}$ & $\begin{array}{c}0.00 \\
(-3.39)\end{array}$ & $\begin{array}{c}0.00 \\
(-3.35)\end{array}$ & $\begin{array}{c}0.00 \\
(-1.69)\end{array}$ & $\begin{array}{c}0.00 \\
(-1.11)\end{array}$ & $\begin{array}{c}0.00 \\
(-3.08)\end{array}$ & $\begin{array}{c}-0.01 \\
(-4.05)\end{array}$ & $\begin{array}{c}0.00 \\
(-0.29)\end{array}$ \\
\hline $\begin{array}{l}\mathrm{N} \text { no event } \\
\mathrm{N} \text { event }\end{array}$ & $\begin{array}{c}22,823 \\
760\end{array}$ & $\begin{array}{c}22,823 \\
760\end{array}$ & $\begin{array}{c}22,823 \\
760\end{array}$ & $\begin{array}{c}23,486 \\
102\end{array}$ & $\begin{array}{c}23,414 \\
173\end{array}$ & $\begin{array}{c}23,068 \\
522\end{array}$ & $\begin{array}{c}23,263 \\
322\end{array}$ & $\begin{array}{c}23,186 \\
404\end{array}$ \\
\hline $\begin{array}{l}\text { Prob. at } 0 \\
\text { Prob. at } 1\end{array}$ & $\begin{array}{l}0.028 \\
0.058\end{array}$ & $\begin{array}{l}0.028 \\
0.045\end{array}$ & $\begin{array}{l}0.028 \\
0.052\end{array}$ & $\begin{array}{l}0.003 \\
0.009\end{array}$ & $\begin{array}{l}0.006 \\
0.015\end{array}$ & $\begin{array}{l}0.020 \\
0.033\end{array}$ & $\begin{array}{l}0.011 \\
0.022\end{array}$ & $\begin{array}{l}0.014 \\
0.025\end{array}$ \\
\hline
\end{tabular}

